OPEN ACCESS

Edited by:

Attila A. Seyhan,

Brown University, United States

Reviewed by:

Irvin Modlin,

Yale University School of Medicine,

United States

Paul B. Fisher,

Virginia Commonwealth University,

United States

${ }^{*}$ Correspondence:

Massimiliano Mazza

massimiliano.mazza@irst.emr.it

Specialty section: This article was submitted to Cancer Molecular Targets and

Therapeutics,

a section of the journal

Frontiers in Oncology

Received: 18 January 2020

Accepted: 28 April 2020

Published: 27 May 2020

Citation:

Bocchini M, Nicolini F, Severi S, Bongiovanni A, Ibrahim T, Simonetti G,

Grassi I and Mazza M (2020)

Biomarkers for Pancreatic

Neuroendocrine Neoplasms (PanNENs) Management-An Updated Review.

Front. Oncol. 10:831

doi: 10.3389/fonc.2020.00831

\section{Biomarkers for Pancreatic Neuroendocrine Neoplasms (PanNENs) Management-An Updated Review}

\author{
Martine Bocchini ${ }^{1}$, Fabio Nicolini ${ }^{1}$, Stefano Severi ${ }^{2}$, Alberto Bongiovanni ${ }^{3}$, Toni Ibrahim ${ }^{3}$, \\ Giorgia Simonetti ${ }^{1}$, Ilaria Grassi ${ }^{2}$ and Massimiliano Mazza ${ }^{1 *}$ \\ ${ }^{1}$ Biosciences Laboratory, Istituto Scientifico Romagnolo per lo Studio e la Cura dei Tumori (IRST) IRCCS, Meldola, Italy, \\ ${ }^{2}$ Nuclear Medicine and Radiometabolic Units, Istituto Scientifico Romagnolo per lo Studio e la Cura dei Tumori (IRST) IRCCS, \\ Meldola, Italy, ${ }^{3}$ Osteoncology and Rare Tumors Center, Istituto Scientifico Romagnolo per lo Studio e la Cura dei Tumori \\ (IRST) IRCCS, Meldola, Italy
}

Pancreatic neuroendocrine tumors (PanNENs) are rare sporadic cancers or develop as part of hereditary syndromes. PanNENs can be both functioning and non-functioning based on whether they produce bioactive peptides. Some PanNENs are well differentiated while others-poorly. Symptoms, thus, depend on both oncological and hormonal causes. PanNEN diagnosis and treatment benefit from and in some instances are guided by biomarker monitoring. However, plasmatic monoanalytes are only suggestive of PanNEN pathological status and their positivity is typically followed by deepen diagnostic analyses through imaging techniques. There is a strong need for new biomarkers and follow-up modalities aimed to improve the outcome of PanNEN patients. Liquid biopsy follow-up, i.e., sequential analysis on tumor biomarkers in body fluids offers a great potential, that need to be substantiated by additional studies focusing on the specific markers and the timing of the analyses. This review provides the most updated panorama on PanNEN biomarkers.

Keywords: pancreatic tumor, pancreatic neuroendocrine tumor, biomarker, neuroendocrine syndrome, FDG (18F-fluorodeoxyglucose)-PET/CT

\section{INTRODUCTION}

Neuroendocrine neoplasms (NENs) are rare and heterogeneous tumors of epithelial origin arising from cells of the neuroendocrine system. Pancreatic NENs (PanNENs) are low incidence diseases accounting for less than $3 \%$ of all pancreatic malignancies but their prevalence is relatively high and is actually rising (1). PanNEN patients account for $8.1 \%$ of total NEN cases (SEER 18) (2), present metastases at diagnosis in $60-80 \%$ of cases (3) and can be subgrouped in functioning (FPanNENs) and non-functioning neoplasms (NF-PanNENs) depending on their ability to secrete active hormones associated with a specific symptomatology. They can occur as sporadic and isolated tumors or in the context of complex hereditary syndromes, such as multiple endocrine neoplasia type 1 (MEN1), von Hippel-Lindau disease (VHL), neurofibromatosis 1, and tuberous sclerosis (4-6). MEN1, in particular, is the commonest syndrome associated with PanNENs and about $10 \%$ of all PanNEN patients are affected by MEN1 syndrome $(1,7)$. PanNENs prognosis differs widely, with some tumors having an indolent nature, with a reasonable length of survival 
even with a metastatic presentation and others being very aggressive with poor prognosis. PanNENs prognosis heterogeneity is in part recognized by the World Health Organization (WHO) classification system. Three independent PanNEN staging systems coexist and are suggested by the European Neuroendocrine Tumor Society (ENETS), the American Joint Committee on Cancer (AJCC) and the World Health Organization (WHO) respectively (2, 8-10). WHO classification is based on cellular proliferation (measured as mitotic count and Ki-67 expression; see Table 1). WHO has recently updated NENs classification whereby well-differentiated NENs are defined Neuroendocrine Tumors (NETs) regardless the grading. This has generated a novel subgroup of welldifferentiated tumors with high Ki-67/mitotic index as G3 and poorly differentiated NENs defined as Neuroendocrine Carcinomas (NEC) which are G3 by definition $(2,8,10)$. The ENETS staging system is based on TNM classification $(1,14)$ whereas the AJCC-draws on the TNM staging for pancreatic adenocarcinoma $(5,9)$; see Table 1 for a comparison). Although the grade of disease is prognostic, several differences in the clinical behavior remain between each subgroup, making personalized treatment challenging for PanNENs. There is a clear unmet clinical need for novel prognostic and predictive biomarkers able to improve grading and staging assessments, guide prognostication and support treatment decisions. We will provide here a general overview of the existing and promising prognostic and predictive biomarkers for PanNENs.

\section{PANCREATIC NENs BIOMARKERS}

Correct diagnosis and accurate staging are of primary importance when treating cancer patients and the use of biomarkers is pivotal in this challenge. An ideal biomarker should display high sensitivity for the diagnosis of NENs, to predict tumor aggressiveness (prognostic biomarker) and/or response to treatment (predictive biomarker) (15). Since several factors impact NEN patients' survival, a multi-analyte approach, which takes into consideration clinical, biochemical, histological and molecular features of the disease is required (16). Several parameters correlate with the overall survival of NEN patients. They include tumor localization, size, grade and stage, vascularization, presence of necrotic tissue and the presence of metastases $(17,18)$. NEN diagnosis starts with the biochemical quantification of circulating analytes in the plasma and/or serum of patients. Neuroendocrine markers can be divided into two main groups: non-specific markers that are virtually produced by all NENs (19) and specific markers that are primarily produced by F-NENs (Table 2 ).

\section{Pancreatic NENs Non-specific Biomarkers}

Non-specific PanNEN biomarkers include chromogranin-A (CHGA), Neuron Specific Enolase (NSE), Pancreatic Polipeptide (PP), Human Chorionic Gonadotropin (HCG), and Alpha Fetoprotein (AFP) (Table 2, Figure 1). Biochemical evaluation of these analytes can be easily performed on serum/plasma fraction of patients with suspected NENs. Aberrant levels of such nonspecific markers should drive further and deepen diagnostic tests (30).

Chromogranin-A (CHGA) is a glycoprotein secreted by neurons and neuroendocrine cells, which is a precursor of bioactive substances such as pancreastatin, catestatin and vastatins I and II (31). Despite all members of granin family can be secreted by neuroendocrine tumors, CHGA is the only one routinely used in clinical practice. The assay has a high sensitivity (32) and good specificity (19). Increased levels of CHGA can be detected both in plasma and serum with a good correlation, suggesting either measurement can provide reliable evaluations of circulating CHGA (33). Circulating CHGA has been reported to correlate with tumor progression (19), presence of metastases (34), tumor burden and response to treatment in NENs, including PanNENs. In fact, CHGA decrease in serum can be considered a surrogate marker for treatment efficacy (35). In contrast, despite two to three-fold increase of CHGA can be considered marker for NENs and also for neuroendocrine differentiation of other non-neuroendocrine cancers, several non-pathological factors, such as food intake (6) and several non-neoplastic endocrine diseases can increase its level in the bloodstream (36), making diagnosis challenging. For those patients affected by concomitant conditions, CHGA assay specificity may decrease up to $50 \%$. Therefore, CHGA should be never considered a first-line diagnostic or screening tool in these sub-populations (37). Despite the above-mentioned limitations, up to now CHGA is the most used liquid biomarker not only in the diagnosis but also during the follow-up of NEN patients.

Neuron Specific Enolase (NSE) is an enzyme found in neurons and neuroendocrine cells, even if only $30-50 \%$, of NENs secretes NSE $(22,32,38)$. This marker may be elevated in $38-40 \%$ of high-grade GEP-NENs, including PanNENs thus providing also prognostic information (39). NSE levels have been directly associated with tumor differentiation, aggressiveness and size $(39,40)$ and it was found to inversely correlate with overall survival (OS) and with progression-free survival (PFS) in ENETS TNM stage IV. NSE has low sensibility but relatively high specificity (see Table 2). Indeed, NSE can be virtually overexpressed also by several non-neuroendocrine tumors, such as parathyroid cancer, prostate carcinoma, neuroblastoma, and it has been correlated with poor differentiation, prognosis and high-grade disease (24). For these reasons NSE alone is rarely used for diagnostic purposes or to distinguish NENs from nonendocrine tumors. Up to date, there is no robust evidence of the predictive role of NSE in predicting therapy efficacy and monitoring patients during follow-up. On the other hand, elevated baseline CHGA/NSE provide prognostic information on PFS and survival in patients with advanced PanNEN treated with the mTOR inhibitor everolimus (41). Evaluation of both NSE and CHGA concentration increases the reliability of NEN diagnosis; however, given the non-specific nature of these markers, they do not provide information on the primary tumor site and its origin (24).

Pancreatic Polypeptide (PP) PP is a 36 amino acid linear oligopeptide, primary secreted by the PP cells of Langerhans' islets (42). Despite its specific role is not well clarified it is 
TABLE 1 | Current WHO grading guidelines and 8th AJCC/UICC-ENETS consensus for pancreatic neuroendocrine neoplasms (11, 12).

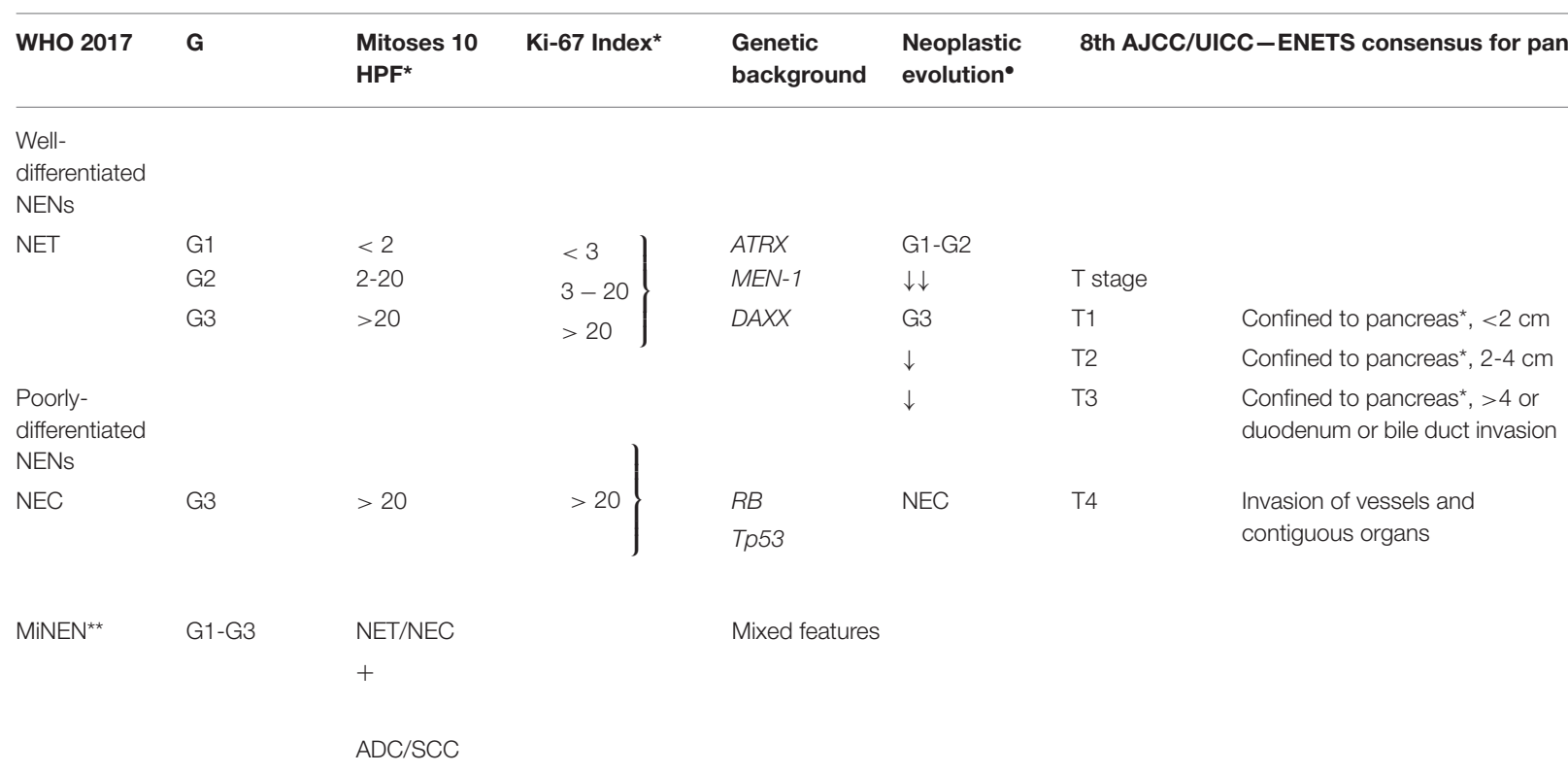

WHO, World Health Organization; NEN, Neuroendocrine Neoplasm; NET/C, Neuroendocrine Tumour/Carcinoma; HPF, Hight Power Field; AJCC, American Joint Committee on Cancer; ENETS, European Neuroendocrine Tumour Society; UICC, Union for International Cancer Control; ADC, Adenocarcinoma; SCC, Squamous cell Carcinoma. • Neoplastic evolution Current classification considers the possibility of an evolution with time of a well-differentiated G1-G2 NEN to a higher G3 and, even more rarely, toward a poorly differentiated NEC (13). **MiNENs (Mixed-NENs): may contain of non- neuroendocrine components (e.g., adeno or squamous) and neuroendocrine ones (at least $30 \%$ for each component) (11). ${ }^{*}$ Specific parameters for PanNET according to 8th AJCC/UICC-ENETS consensus.

supposed to regulate pancreatic, GI secretions (32) and hepatic glycogen levels (38). PP is generally considered a neuroendocrine differentiation marker with good specificity but low and variable sensitivity (30) (Table 2). Since 2015, PP has been suggested for the diagnosis of PanNENs (NCCN guidelines) (43) and ESMO 2012 consensus guidelines already considered PP diagnostic also for NF-PanNENs (29). Despite PP has been observed to be elevated in metastatic disease with increased sensitivity (up to $80 \%$ ) (44), $<50 \%$ of PanNEN patients presents with elevated serum PP (19). Additionally, serum concentrations of PP can be increased by many factors, including physical exercise, hypoglycemia, and food intake (32), as well as decreased by somatostatin and hyperglycemia, diarrhea, laxative abuse, increased age, GI inflammatory processes and chronic renal disease (45). Detection of high levels of circulating PP, together with CHGA is suggestive for PanNENs with increased sensitivity $(30,42)$. Production of PP and/or CHGA is observed in $100 \%$ of spontaneous and hereditary gastrinomas (46). In contrast, decline of PP level during patients monitoring is considered a good prognostic marker (19).

Finally, human chorionic gonadotropin (HCG) and alphafetoprotein (AFP) can be also considered in biochemical assessment of certain malignancies, although their use is limited (24). HCG is a glycoprotein physiologically synthesized by syncytiotrophoblastic cells of the placenta during pregnancy $(24,32)$ and it is composed of $\alpha$ and $\beta$ subunits. The $\beta$ subunit ( $\beta$-HCG) is specific, since tumor cells usually lack the mechanism to link $\alpha$ and $\beta$ subunits. An increased secretion of the $\beta$ subunit is reported in pancreatic tumors and PanNENs. AFP is a peptide hormone produced during development. In adults increase of
AFP in serum has been reported in NENs $(25,26)$. AFPproducing PanNENs are rare and often associated with other malignancies $(47,48)$. However, the literature is controversial on the sensitivity and specificity HCG and AFP, thus limiting their use in NENs $(37,49)$.

\section{PanNENs Specific Biomarkers}

Bioactive peptides retrieved in the blood of F-PanNEN patients are useful prognostic and predictive biomarkers (24). However, hormones are not always secreted and retrievable from the blood. Indeed, evaluation of expression directly on the neoplastic tissue is the gold standard for diagnosis. In addition, symptoms associated with their increased levels help both to diagnose and to identify the primary site of disease (50). F-PanNENs are named after the hormones they produce as insulinomas, glucagonomas, gastrinomas, somatostatinomas, VIPomas, which are suggestive of their cell-of-origin.

\section{Circulating Biomarkers}

Gastrin (GAS) is a linear peptide hormone secreted by G-cells of pyloric antrum, duodenum and pancreas implicated in the regulation of chloride acid release from parietal cells in the stomach, gastric motility and pancreatic secretion. A plasma concentration of GAS $>300 \mathrm{pg} / \mathrm{mL}$ correlates with the presence of gastrinomas, even if GAS is secreted as well by functioning NENs especially in the context of MEN-1 and Zollinger-Ellison syndrome (ZES) (32).

Insulin (INS) is a dimeric peptide hormone of 51 amino acids, physiologically secreted by the $\beta$ cells of the pancreatic islets in response to glycemia increase and 
TABLE 2 | Biochemical biomarkers in use for PanNEN diagnosis, prognosis, and treatment monitoring.

\begin{tabular}{|c|c|c|c|c|c|c|c|c|c|}
\hline \multicolumn{3}{|c|}{ Biochemical markers } & $\begin{array}{l}\text { Source } \\
\text { Serum }\end{array}$ & $\begin{array}{l}\text { Level } \\
\begin{array}{l}63-14.750 \\
\mathrm{ug} / \mathrm{l}\end{array}\end{array}$ & $\begin{array}{l}\text { Sens. } \\
\text { (\%) } \\
60-83\end{array}$ & $\begin{array}{l}\text { Spec. (\%) } \\
72-85\end{array}$ & $\begin{array}{l}\text { Combinations } \\
\text { improving } \\
\text { sens./spec. }\end{array}$ & $\begin{array}{l}\text { Clinical use } \\
\text { For diagnosis and } \\
\text { follow up in } \\
\text { GEP-NENs and } \\
\text { treatment monitoring }\end{array}$ & $\begin{array}{c}\text { References } \\
(20,21) \\
(22,23)\end{array}$ \\
\hline & $\begin{array}{l}\text { Pancreatic- } \\
\text { Polipetide }\end{array}$ & PP & Plasma & $\begin{array}{l}\text { 480-780 } \\
\mathrm{pg} / \mathrm{ml}\end{array}$ & $31-63$ & 67 & $\mathrm{CHGA}$ & $\begin{array}{l}\text { For diagnosis and } \\
\text { follow up in } \\
\text { PanNENs }\end{array}$ & (23) \\
\hline & $\begin{array}{l}\text { Human Corionic } \\
\text { Gonadotropin }\end{array}$ & HCG & Serum & Increased & na & $\mathrm{Na}$ & $\begin{array}{l}\text { AFP; CHGA; PP; } \\
\text { HCG }\end{array}$ & $\begin{array}{l}\text { Indicative of } \\
\text { pancreatic origin }\end{array}$ & (24) \\
\hline \multirow[t]{3}{*}{ Specific } & Gastrin & GAS & Serum & $\begin{array}{l}\geq 300 \\
\mathrm{pg} / \mathrm{mL}\end{array}$ & 94 & 100 & MEN-1; ZES & $\begin{array}{l}\text { Diagnostic for } \\
\text { Gastrinoma of } \\
\text { pancreatic origin }\end{array}$ & $(24,27)$ \\
\hline & Insulin & INS & $\begin{array}{l}\text { Serum/ } \\
\text { Plasma }\end{array}$ & $\begin{array}{l}\geq 43^{\circ} \\
\mathrm{pmol} / \mathrm{L}\end{array}$ & $52-94$ & $92-100$ & Whipple's triad & $\begin{array}{l}\text { Diagnostic for } \\
\text { Insulinoma; } \\
\text { suggesting for WD } \\
\text { NETs. }\end{array}$ & (28) \\
\hline & Glucagon & GCG & Plasma & $\begin{array}{l}\text { 500-1000 } \\
\mathrm{pg} / \mathrm{mL}\end{array}$ & High & High & - & $\begin{array}{l}\text { Diagnostic for } \\
\text { Glucagonoma; } \\
\text { suggesting for WD } \\
\text { NETs; Indication for } \\
\text { liver metastases }\end{array}$ & (24) \\
\hline
\end{tabular}

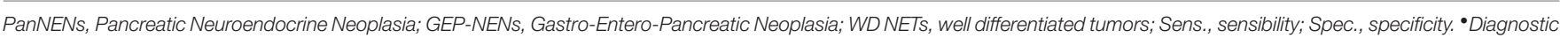
serum/plasma level in association with specific syndrome. ${ }^{\circ}$ Somatostatin increase is very a-specific, increase SS level with SSoma syndrome is suggesting for GEP-NENs.

involved in the regulation of body anabolism. INS can increase as a consequence of several oncologic and nononcologic conditions, therefore, its concentration alone does not represent a solid marker for insulinoma. Insulinoma should be suspected when patients display the so-called "Whipple's triad" symptoms: clinical evidence of hypoglycemia, serum glucose $\leq 40 \mathrm{mg} / \mathrm{dL}$ and improvement following administration of glucose (51).

Glucagon (GCG) is a peptide hormone secreted by pancreatic $\alpha$-cells to increase catabolism thereby mobilizing energy reserves to free glucose molecules via gluconeogenesis and glycogenolysis. An increased plasma GCG level $>500 \mathrm{pg} / \mathrm{mL}$ is indicative of glucagonoma albeit requires further diagnostic work-up to exclude non-oncologic reasons. By contrast, GCG levels $>1000$ $\mathrm{pg} / \mathrm{mL}$ are diagnostic for glucagonoma and used in the clinical practice (52).
Somatostatin (SST) is a peptide hormone physiologically secreted by pancreatic $\delta$-cells, APUD cells and gastric antrum D cells (53). SST can repress GCG and INS secretion by $\alpha$ and $\beta$ cells of the pancreas, respectively. SST excess induces nonspecific manifestations and it can result in the formation of gallstones, intolerance to fat in the diet, diarrhea and diabetes. Furthermore, increased levels of SST are not only associated with somatostatinoma of the pancreas but also with various extra-Pancreatic NENs (54). Hence, SST level per se is not sufficient to diagnose somatostatinoma but it requires very careful clinical assessment.

Vasoactive Intestinal Peptide (VIP) is a peptide hormone released by pancreatic and brain cells. It is both a neurotransmitter and a potent vasodilator regulating smooth muscle activity, epithelial cell secretion and blood flow in the gastrointestinal tract. VIPoma, a non- $\beta$ pancreatic islet cell 


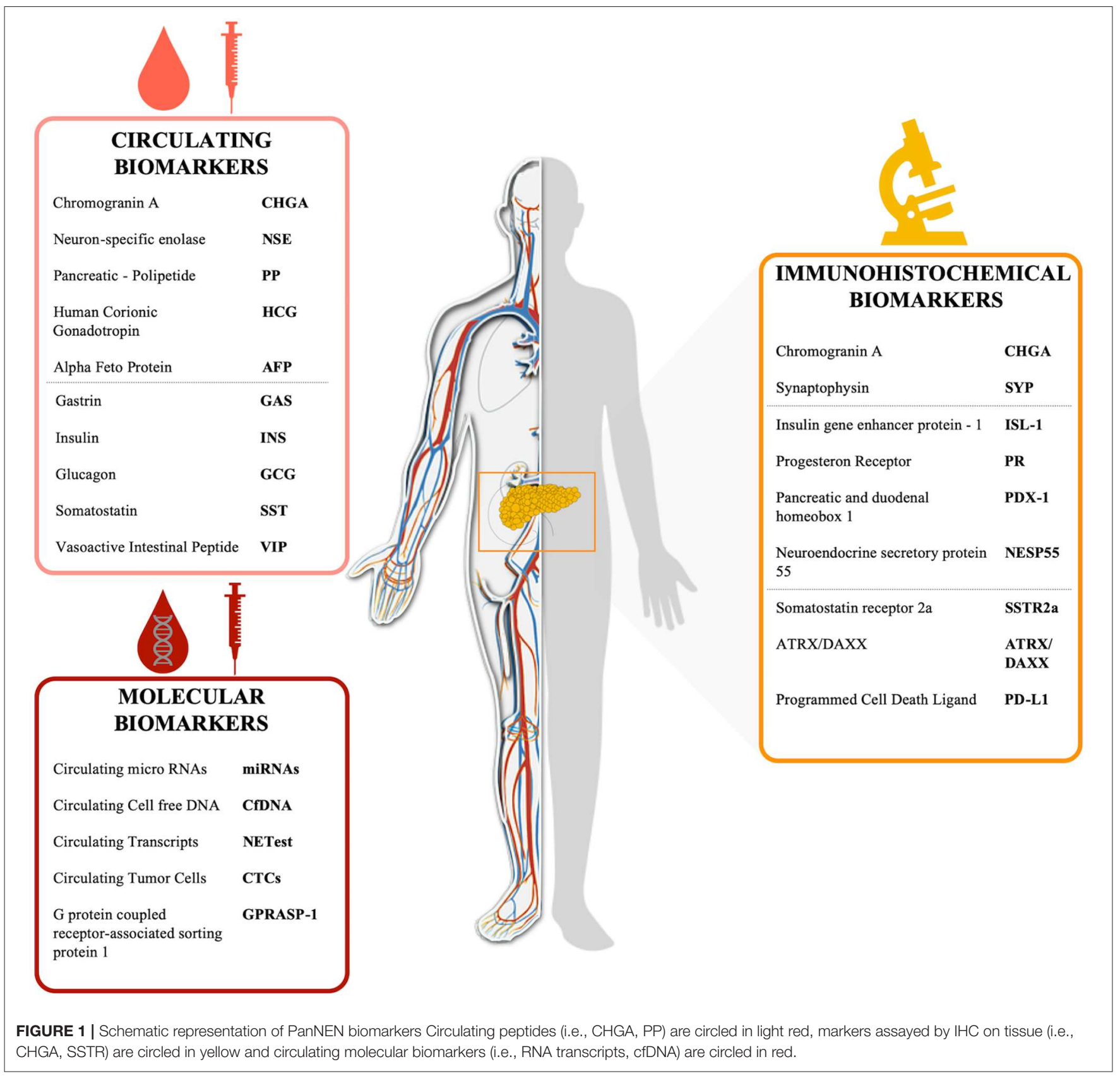

tumor, shows a syndrome of watery diarrhea, hypokalemia, and achlorhydria (WDHA syndrome) and it is diagnosed by a serum VIP concentration above $200 \mathrm{pg} / \mathrm{dL}$. A mild increase in VIP concentration $(75-200 \mathrm{pg} / \mathrm{dL})$ can be also considered in patients with Verner Morrison syndrome (29). These biomarkers can be suggestive of a PanNEN. However, symptoms can often be nuanced or aspecific, and careful clinical and histo-pathological assessment remains mandatory.

\section{Tissue Biomarkers}

Histological diagnosis is usually assessed on surgical or endoscopic biopsies, on which morphological and marker distribution analysis is performed by immunohistochemistry
(IHC) (29) (Table 3). PanNENs can also produce hormones that are not subsequently secreted, and specific stains for GAS, INS, and SST can confirm clinical symptoms without biochemical increase in serum. However, IHC alone for hormones and bioactive peptides cannot prove site of origin and confirm functionality of NENs (29). At present chromogranin A (CHGA) and synaptophysin (SYP) are considered the most specific markers for NEN differentiation by immunohistochemistry (62). CHGA is contained in the granules of neurons and pancreatic cells, it is a precursor of several functional peptide hormones such as vasostatins and pancreastatin. CHGA is widely expressed in well-differentiated NENs whereas generally low or focally positive in poorly-differentiated NEC (55). SYP is an integral 
TABLE 3 | Immunohistochemical (IHC) biomarkers for PanNENs diagnosis, prognosis and treatment monitoring.

\begin{tabular}{|c|c|c|c|c|c|c|c|}
\hline \multicolumn{3}{|c|}{ Immunohistochemical markers (IHC) } & \multirow{2}{*}{$\begin{array}{l}\text { Source } \\
\text { Surgical/endoscopic } \\
\text { biopsy }\end{array}$} & \multirow{2}{*}{$\begin{array}{l}\text { Level } \\
\text { Over-expressed }\end{array}$} & \multirow{2}{*}{$\begin{array}{l}\text { Combinations } \\
\text { improving sens./spec. } \\
\text { SYP }\end{array}$} & \multirow{2}{*}{$\begin{array}{l}\text { Clinical use } \\
\text { Diagnosis of NENs; } \\
\text { Grading; Differentiation }\end{array}$} & \multirow{2}{*}{$\begin{array}{c}\text { References } \\
\text { (23) } \\
(24)\end{array}$} \\
\hline Differentiation & Chromogranin A & CHGA & & & & & \\
\hline & Synaptophysin & SYP & $\begin{array}{l}\text { Surgical/endoscopic } \\
\text { biopsy }\end{array}$ & Over-expressed & CHGA & $\begin{array}{l}\text { Diagnosis of GEP-NENs; } \\
\text { grading; differentiation }\end{array}$ & $(24)$ \\
\hline \multirow[t]{4}{*}{ Site of Origin } & $\begin{array}{l}\text { Insulin gene } \\
\text { neanche } \\
\text { homeeobox - } 1\end{array}$ & ISL-2 & $\begin{array}{l}\text { Surgical/endoscopic } \\
\text { biopsy }\end{array}$ & $\begin{array}{l}\text { Over-expressed in } \\
\text { endocrine pancreas }\end{array}$ & $\begin{array}{l}\text { Low expression in case } \\
\text { of Gastrinoma }\end{array}$ & $\begin{array}{l}\text { Over-expressed in Pan } \\
\text { NENs (especially in WD } \\
\text { tumors) }\end{array}$ & $(55)$ \\
\hline & $\begin{array}{l}\text { Progesteron } \\
\text { Receptor }\end{array}$ & PGR & $\begin{array}{l}\text { Surgical/endoscopic } \\
\text { biopsy }\end{array}$ & Positive & $\mathrm{CHGA}+\mathrm{SYP}$ & $\begin{array}{l}\text { Indicative of pancreatic } \\
\text { origin (40-75\%) (negative } \\
\text { in Gl-NENs) }\end{array}$ & $(56)$ \\
\hline & $\begin{array}{l}\text { Pancreatic and } \\
\text { duodenal } \\
\text { homeobox } 1\end{array}$ & PDX-1 & $\begin{array}{l}\text { Surgical/endoscopic } \\
\text { biopsy }\end{array}$ & Positive & CHGA + SYP & $\begin{array}{l}\text { Indicative of pancreatic } \\
\text { origin }\end{array}$ & $(57)$ \\
\hline & $\begin{array}{l}\text { Neuroendocrine } \\
\text { secretory protein } \\
55\end{array}$ & NESP55 & $\begin{array}{l}\text { Surgical/endoscopic } \\
\text { biopsy }\end{array}$ & Focally positive & CHGA + SYP & $\begin{array}{l}\text { Indicative of pancreatic } \\
\text { origin }(40-50 \%)\end{array}$ & $(56)$ \\
\hline \multirow[t]{3}{*}{$\begin{array}{l}\text { Prognostic/ } \\
\text { Predictive }\end{array}$} & $\begin{array}{l}\text { Somatostatin } \\
\text { receptors } 2 \mathrm{a}\end{array}$ & SSTR2a & $\begin{array}{l}\text { Surgical/endoscopic } \\
\text { biopsy }\end{array}$ & Over-expressed & CHGA + SYP & $\begin{array}{l}\text { Indicative of pancreatic } \\
\text { origin; Predictive for } \\
\text { PRRT treatment; inverse } \\
\text { correlation with grading. }\end{array}$ & $\begin{array}{l}(58) \\
(59)\end{array}$ \\
\hline & ATRX/DAXX & ATRX/ DAXX & $\begin{array}{l}\text { Surgical/endoscopic } \\
\text { biopsy }\end{array}$ & Loss of expression & CHGA + SYP & $\begin{array}{l}\text { Prognostic for tumor } \\
\text { aggressiveness; } \\
\text { (associated with WD } \\
\text { tumors) }\end{array}$ & $(60)$ \\
\hline & $\begin{array}{l}\text { Programmed Cell } \\
\text { Death Ligand }\end{array}$ & PD-L1 & $\begin{array}{l}\text { Surgical/endoscopic } \\
\text { biopsy }\end{array}$ & Over-expressed & CHGA + SYP & $\begin{array}{l}\text { Prognostic/Predictive for } \\
\text { anti-PD-L1 therapeutic } \\
\text { agents }\end{array}$ & $(61)$ \\
\hline
\end{tabular}

PanNENs, Pancreatic Neuroendocrine Neoplasia; GEP-NENs, Gastro-Entero-Pancreatic Neoplasia; WD NETs, well differentiated tumors.

transmembrane glycoprotein expressed in neuroendocrine cells and neurons involved in synaptic transmission with a diffuse cytoplasmic immunostaining (63). CHGA and SYP combined assessment represents the first of a multi-step approach currently in use to confirm the neuroendocrine nature of the disease and then its pancreatic origin.

\section{EMERGING MARKERS IN PanNEN}

\section{Tissue Biomarkers}

Besides the validated diagnostic markers, other tissue biomarkers are under investigation to improve PanNENs management providing information on the site of origin, grading, immune and genetic landscape of the disease. In addition, novel biomarkers could be new therapeutic targets. Up to now several immunohistochemical panels have been proposed to identify primary tumor site of origin, especially in NENs of the gastro-entero-pancreatic (GEP-NENs) tract. Although many recent studies focused on these biomarkers they are not routinely used and validated for diagnosis and/or prognosis in PanNENs management.

Islet 1 (ISL-1) is a homeobox transcription factor expressed in all endocrine pancreatic cells (57). This pattern of expression suggests a general role in the development of multiple cell lineages of the endocrine pancreas. ISL-1 expression is detected in $70-82 \%$ of panNENs (64). Unfortunately, other GI-NENs, in particular NENs of the rectum, overexpress this marker (65) and gastrinomas of the pancreas show low expression of ISL-1 making its application as a general PanNEN diagnostic biomarker troublesome.

Progesteron Receptor (PR), represent a widely-studied, but still incoming and more specific pancreatic marker. Nuclear positivity for PR has been reported in most pancreatic endocrine tumors, and recent studies confirm PR expression in 40$75 \%$ of PanNENs $(56,64)$. In addition, PR immunoreactivity has been demonstrated to be strictly confined to endocrine compartment of normal and neoplastic human pancreatic islets $(56,64)$ and to be significantly associated with a favorable prognosis and a lower clinical stage (66). The relative expression of $\mathrm{PR}$ isoforms (PRA; $\mathrm{PRB}$ ) have been reported to have a prognostic role in NENs from different site of origin (e.g., breast) $(67,68)$. Recent findings focused on the role of PRA and PRB in PanNENs demonstrated that PRB activation promotes Cyclin D1 (CCND1) overexpression and, as a consequence of c-Fos and c-Jun induction transcription factors supporting cell proliferation and tumorigenesis (69). In addition, progesterone signaling via PRA could inhibit tumorigenesis by $\mathrm{PRB}$ suppression. In addition, PRA can be a suitable predictive factor in PanNEN and inversely correlated with tumor progression (70).

Neuroendocrine secretory protein 55 (NESP55) is a protein belonging to the chromogranin family which can be considered 
highly specific marker for PanNENs, since other GI-NENs subtypes show low to none expression of this protein (64). Recent findings report focal and specific expression of NESP55 in $40-74 \%$ of PanNENs in contrast with very rare expression observed in other GI-NENs and NENs of the lung and rectum (5 and $8 \%$, respectively) $(64,71)$.

Paired box 8 (PAX 8) represents a transcription factor able to regulate organogenesis in a variety of organs (72). Although PAX8 has been considered a marker for renal development and neoplasms, Sangoi et al. observed high PAX8 reactivity in PanNENs and normal pancreatic islets in a large tissue microarray evaluation (73). In contrast with ileal or pulmonary NETs and NENs of duodenum, stomach, and rectum which were negative to PAX8 staining or show very low expression, respectively. PAX8 has been demonstrated to be particularly useful in metastatic NENs with unknown primary tumor site, the expression PAX8 in combination with ISL-1 could indicate pancreatic origin (5).

Pancreatic and duodenal homeobox 1 (PDX-1) is transcriptional activator of several genes, including insulin, somatostatin, glucokinase, islet amyloid polypeptide, and glucose transporter type 2 (74). PDX-1 immunoreactivity is reported in $54-100 \%$ of PanNENs (64). Despite PDX-1 can be expressed also by other GI-NENs, NENs of the ileum have been reported to be negative for PDX1 thus it can be useful, especially when used in combination with ISL-1, PAX8, and/or NESP55 in defining pancreatic site of origin when it is unclear. In addition, PDX-1 is involved in the early development of the pancreas and plays a key role in glucose-dependent regulation of insulin gene expression (74).

Among those, combinations of Islet 1 (ISL-1), Progesteron Receptor (PR), neuroendocrine secretory protein 55 (NESP55), paired box 8 (PAX8), and Pancreatic and duodenal homeobox 1 (PDX1) suggest pancreatic origin (73, 75-77). In addition, the well-known Somatostatin Receptors (SSTRs) and GLUT-1 are companion markers for imaging techniques which fulfill a primary role in PanNEN diagnosis and prognosis.

Somatostatin receptors $2 a$ and 5 (SSTR2a and SSTR5) have been widely studied as prognostic and predictive biomarker in GEP-NENs since most of GEP-NENs shows diffuse SSTRs overexpression (78), especially G1 and G2 stage tumors (79). Indeed, an inverse correlation between SSTR2a expression and NENs differentiation has been observed (80). SSTR2a is particularly over-expressed in PanNETs compared to NENs of different origin (e.g., GI-NENs/NEC). SSTRs represent the molecular target for ${ }^{68}$ Gallium-labeled compounds and PET/CT ( ${ }^{68} \mathrm{Ga}$ - PET/CT scan) that has recently become the gold standard for the diagnosis and management of these tumors. Recent study by Liverani et al. observed an inverse correlation between ${ }^{68} \mathrm{Ga}$ - PET/CT uptake and tumor differentiation in a small GEPNENs subsets (81). Therefore, SSTR2 can be considered for both diagnostic and therapeutic purposes. Intriguingly, SSTR2 is more expressed in primary PanNENs than in metastases (82), suggesting a novel additional role of SSTR2a in monitoring the tumor progression (79). Most of those biomarkers are not yet used in clinical practice. However, multianalyte combinations should show higher sensitivity and might be more effective than the current use of monoanalytes as shown in some studies (83, 84). Several peptides and growth factors have been explored as biomarkers for PanNENs to improve early diagnosis and followup of NENs, among these $\alpha$-Internexin, Paraneoplastic antigen 2 (PNMA2) and X-linked inhibitor of apoptosis (XIAP) are emerging immunocytochemical markers.

Glucose transporter 1 (GLUT-1) is a uniporter protein that mediates the transport of glucose molecules through the cell membrane. GLUT-1 is observed to be overexpressed in several tumors, probably related with higher metabolism and cell growth (85). Several studies have shown association between GLUT-1 expression and tumor aggressiveness, poor prognosis and neuroendocrine differentiation in a number of carcinomas (86-88). Fujino, M. et al. investigated the prognostic role of GLUT-1 in G1/G2 PanNENs. GLUT-1 overexpression correlates with grading, Ki-67 mitotic index, vessel invasion, lymph node metastases and poor disease free survival rate (89). In addition, HIF-1 $\alpha$ overexpression was observed in GLUT1 positive cases, suggesting a HIF-1 $\alpha$ dependent induction of GLUT-1 in hypoxic conditions (89). In addition, GLUT-1 over expression in NENs correlates with an increased uptake of 2 deoxy-2-[fluorine-18] fluoro-D-glucose and positivity in PETCT (90). High ${ }^{18}$ F-FDG uptake is a useful prognostic marker in PanNENs (91), thereby GLUT-1 expression may be a good surrogate prognostic marker for ${ }^{18}$ F-FDG captation. Altogether those evidences suggest that GLUT-1 expression might be taken into consideration for PanNENs prognostic assessment. Since ${ }^{18}$ F-FDG uptake by PanNENs is a valuable prognostic marker associated with important aspects of tumor metabolism it is becoming of paramount importance to find biomarkers that correlate with this status for longitudinal analyses in patients. In line with this observation, our preliminary data, presented at the 2019 ESMO meeting reported a prognostic miRNA signature associated with ${ }^{18} \mathrm{~F}-\mathrm{FDG}$ PET status in PanNENs (92).

Programmed Cell Death Ligand (PD-L1), a protein involved in the immune checkpoint, is recently observed to be strongly upregulated in G3 tumor patients both on tumor and infiltrating immune cells, resulting in poor T-cell-mediated tumor surveillance (93). Thus, PD-L1 expression may represent a predictive biomarker for GEP-NENs patients who may benefit from immunotherapy (94). Interestingly, it has been recently reported that DAXX and ATRX molecular alterations correlate with increased tumor-associated macrophage (TAMs) infiltration thereby with inferior Disease Specific Survival rates, suggesting TAMs as potential prognostic biomarkers and targets for immune-modulating therapies in PanNETs (61). Finally, latest publications and communications at international meetings propose novel tissue markers with diagnostic, prognostic and/or therapeutic markers for PanNENs, such as Delta-like protein 3 (DLL-3). Interestingly, PD-L isoform 2 (PD-L2) has been found significantly overexpressed $(p<0.001)$ in PanNENs compared to non-pancreatic NENs (e.g., lung) (95). The same study identified that PD-L2 inversely correlates with presence of tumor necrosis and with PD-L1 expression levels $(p<0.03)$.

DLL-3 is a member of the Notch ligand family that is aberrantly expressed on the cell surface of Small cell lung 
cancer (SCLC), Merkel cell Carcinoma (MCC) (96) and other neuroendocrine tumor cells (96-99) making it an attractive therapeutic target in NECs as proposed at latest international conferences, including AACR (96) and ESMO 2019 (100) annual meetings (96) and tested in ongoing trials on SCLC (TAOHE, NCT0306181).

$\alpha$-Internexin is a cytoskeleton protein involved in tumorigenesis and disease progression (101) and is overexpressed in nervous system cell but also in insulinomas (102). Its evaluation in tumor tissue specimens has been observed to be useful as monoanalyte to predict and monitor treatment efficacy in insulinomas $(102,103)$. Furthermore, combination of $\alpha$ Internexin and $\mathrm{Ki}-67$ mitotic index, as prognostic multianalytes tests, is observed to predict tumor aggressiveness in insulinomas $(89,104-107)$. Loss or reduced expression of $\alpha$-internexin protein represents potential prognostic marker for non-insulinomas PanNENs in terms of overall survival (OS) (102).

Paraneoplastic antigen 2 (PNMA2) is a neuronal antigen identified as marker of neurological paraneoplastic syndromes (108). PNMA2 shows correlation with disease progression and recurrence free survival in PanNENs (109).

$\mathrm{X}$-linked inhibitor of apoptosis (XIAP) suppresses apoptosis in cancer cells $(110,111)$. It is a prognostic factor in cancer patients. Despite its role in PanNENs is not well established it is overexpressed in neuroendocrine GI tract and can represent a potential target for therapies (112-114).

Novel forthcoming DNA/RNA markers are also studied. DNA/RNA markers usefulness is mainly explored in the bloodstream via non-invasive liquid biopsy. Nevertheless, detection, analysis, and data interpretation of liquid markers are challenging and still under development. For this reason, many studies explored the expression pattern of DNA/RNA markers and/or molecular mechanisms, such as alternative lengthening of telomeres (ALT), non-coding RNAs, and mutational patterns also and primarily on tumor tissue specimens.

ALT is a tissue DNA prognostic marker for NENs. In PanNENs, ALT was shown to correlate with inactivating mutations in ATRX/DAXX genes $(115,116)$. Despite the literature is controversial about it, ALT expression is associated with larger tumor size, grading, vascular/perineural invasion and metastasis $(117,118)$. In contrast, other studies have found association with prognosis $(119,120)$.

MicroRNAs (miRNAs) are 21-24 nucleotides non-coding RNAs (ncRNAs) that interfere with gene expression. A plethora of studies have been performed and propose specific tissue miRNA signatures to distinguish PanNENs patients from healthy individuals and the primary tumor from the metastatic disease with a prognostic and/or predictive role. For example, Roldo et al. described a tumor specific miRNA signature defined by miR-103 and miR-107 expression and by the absence of miR-155 expression distinguishing PanNEN from normal pancreatic tissue (121). Furthermore miR-204 is primarily expressed in insulinomas and correlates with insulin expression on tissue (122).

\section{Genetic Alterations Promoting Nen Development}

Before the last decade genetic studies on molecular alterations of GEP-NENs were limited and mainly based on data from genetic syndromes associated with endocrine neoplasms. The diffusion and fruition of next-generation sequencing and other high-throughput techniques (microarray expression, miRNAs, and methylome analyses) in recent years have provided a larger amount of genetic and epigenetic information and a wider view of these malignancies, and especially of PanNENs, from a genetic perspective as reviewed in a very comprehensive manner by several authors (119, 123-130).

This information improved patients' stratification. Indeed, the WHO 2017 update for PanNENs proposed the separation of PanNECs and PanNENs, based on molecular alterations and regardless of the grading $(14,131-133)$. TP53 and RB1 combined loss has been confirmed to be driver mutation of pancreatic carcinoma development. PanNECs represent the 7, 5\% of all PanNENs (134) and they are characterized by TP53 and RB1 inactivating mutations $20-73$ and $71 \%$, respectively while NENs, including G3 NENs with higher Ki-67 percentage and proliferation index do not display these mutations $(124,125,134-$ 138). RB1 is a key negative regulator of the cell cycle via p16 and other proteins. Indeed, loss of p16 immunostaining has been reported in $20-44 \%$ PanNECs, alone or in combination with $\mathrm{Rb}$ loss (134, 139-142). Interestingly, RASSF1A, another cell cycle repressor of downstream to $\mathrm{Rb}$ displayed methylation of the promoter in $10-60 \%$ of PanNECs, pinpointing the crucial role of cell cycle deregulation in carcinomas tumorigenesis (143146). Interestingly TP53 inactivation and/or P53 protein nuclear accumulation have been identified in $20-70 \%$ and $65-100 \%$ of PanNECs respectively (134, 142, 147-149).

A specific mutational pattern has been also reported for PanNENs, that lack $R B / T P 53$ mutations or an impaired RB/P53 expression. These tumors frequently display DAXX/ATRXX (925\%) and MEN-1 (10-36\%) mutations or protein impaired expression $(150,151)$. The first whole-exome study on PanNETs, identified ATRX and DAXX as mutated genes, located in the chromatin remodeling compartment (119). ATRX/DAXX loss occurs in 18 and $25 \%$ of PanNETs and leads to ALT phenomenon, chromosomal instability and higher tumor stage suggesting this mutation is a late event in the neoplastic transformation (116, 152, 153). A second effect of $A T R X / D A X X$ alteration concerns PTEN and, as consequence the inhibition of the PI3K/mTOR pathway $(117,119,154,155)$.

In addition, whole-genome/exome studies identified PTEN and TSC1/2 as potential driver mutations in NENs development when compared to carcinoma tumorigenesis, with a frequency of inactivating lesions among PanNEN cases of 7 and 6\%, respectively $(119,156)$. These alterations, in particular RB1/TP53 loss, are particularly important for diagnosis and prognosis to distinguish NECs from G3 PanNENs, especially in challenging cases as when morphology and immunostaining are unreliable $(131,132,151,157,158)$. 


\section{Germline Mutations and Sporadic PanNEN Development}

Genetic studies on molecular alteration of GEP-NENs has been limited and mainly based on data from genetic syndromes associated with endocrine neoplasm for a long time. Genetic syndromes with recurrent germline mutated genes such as MEN, VHL, NF1, and TS (159-164)have been demonstrated to favor GEP-NENs development in about $10 \%$ of all NENs (4). Interestingly, somatic mutations on the same genes have been reported to promote sporadic PanNEN onset, with variable frequencies. Data derived from hereditary syndromes first, and from sequencing of sporadic PanNENs later, highlighted the involvement of two main pathways in PanNENs development: cyclin-dependent cell cycle regulation (MEN-1) and the $\mathrm{PI} 3 \mathrm{~K} / \mathrm{mTOR}$ pathway (MEN-1, VHL, NF-1, TS).

Multiple Endocrine Neoplasia type I is an autosomal dominant disease, promoting the development of pancreatic endocrine tumors in $60 \%$ of patients (165). It is caused by germline-inactivating mutations in the MEN-1 gene $(166,167)$ and by subsequent somatic loss of the normal allele (168). MEN1 gene alteration has been also reported in $44 \%$ of sporadic NETs (127). For these reasons it is considered one of the main genes involved in NET biology $(119,156,169-173)$. MEN-1 loss affects a large number of cellular activities, including (a) histone methylation and expression of the CDKN2C/CDKN1B cell cycle inhibitors (174); (b) PI3K/mTOR signaling via Akt (175); (c) homologous recombination (HR) through interactions with DNA repair complexes (e.g., RAD51 and BRCA1) $(176,177)$. In addition, MEN-1 mutations have been associated with loss of P27 as an early alteration in NET development (178).

Von Hippel-Lindau disease is caused by inactivating mutations of the VHL gene. VHL is observed to be inactivated also by deletion or methylation in up to $25 \%$ of sporadic PanNETs (127). VHL inactivation leads to the activation of the hypoxia induced pro-proliferative signaling $(179,180)$.

Neurofibromatosis type I disease derives from germline mutations of NF1 that are associated with NEN development in $10 \%$ of patients affected by the syndrome. NF1 protein product is a negative regulator of PI3K/mTOR pathway which holds a key role in NEN tumorigenesis $(169,181)$. Nevertheless, NF1 has been rarely reported to be mutated in sporadic PanNENs (127).

Inactivating mutations in TS lead to Tuberous Sclerosis Complex (TSC) syndrome and to sporadic PanNENs in 35\% of cases (127). This is caused by inactivation of TSC1 and TSC2, thus inhibiting $\mathrm{PI} 3 \mathrm{~K} / \mathrm{mTOR}$ signaling downstream of AKT1 $(119,182)$.

\section{Chromosomal and Epigenetic Alterations}

Mutational events alone cannot be traced back and explain all cases of NEN. Evidence points instead to chromosomal and/or epigenetic alterations as origin of neuroendocrine transformation in about $50 \%$ of cases. CNV analysis and whole-genome sequencing $(117,124,156)$ allowed the definition of four PanNENs subtypes based on chromosomal alterations: (i) loss of chromosome 11q (where MEN1 resides); (ii) a recurrent pattern of whole chromosomal loss (RPCL) in association with higher mitotic index, ALT and ATRX/DAXX inactivation; (iii and iv) patterns of chromosome gaining, complementary to losses of the RPCL group and associated with higher risk of metastasis $(126,183-187)$. In addition, whole-genome mutational analysis, identified $10 \%$ of germline mutations in base-excision repair $(M U T Y H)$ and homologous recombination repair (BRCA2, CHEK2) genes $(119,182)$.

From a transcriptional perspective PanNENs have been classified into 3 subtypes, which are related to key pathways of NEN disease, namely, chromatin remodeling in MEN1-like tumors, PI3K/mTOR in insulinoma-like tumors and hypoxiarelated genes in the metastasis-like primarytumors cluster (188).

DNA methylation alteration is also found and is associated with PanNETs. Hyper-methylation of RASSF1A, HIC-1, CDKN2A, VHL, and MGMT genes for example has been reported in a large fraction of PanNETs (189-191). In contrast, hypo-methylation was reported for ALU and LINE1. In particular LINE1 has been associated to poor prognosis and chromosomal instability in ATRX/DAXX negative tumors $(190,192,193)$.

\section{Liquid Forthcoming Markers in PanNENs}

Three key methods allow a comprehensive assessment of the neuroendocrine disease: clinical evaluation, imaging, and biomarkers assessment $(62,84,194)$. Imaging is complex, based on sophisticated and expensive technologies, and often fails to predict early changes of the disease and to anticipate progressions or resolve pseudo-progressions (195). In addition, standard serial CT/MRI imaging have well-described sensitivity limitations (196) and may even provide false negative output in comparison to functional imaging ${ }^{68} \mathrm{Ga}$-somatostatin analogs (SSA)-PET/CT $(197,198)$. Furthermore, imaging can be invasive as it exposes patients to repetitive radiation sessions. Both clinical and imaging strategies, have high intra-observer variability and are operator-dependent (199). In contrast, blood biomarkers represent an easy-to-detect and non-invasive method to evaluate disease with objective measurements $(62,84)$. The advent of sophisticated and sensitive technologies has revolutionized the concept of biopsy, changing the focus from a tumor tissueoriented framework to a systemic vision of the disease. Liquid biopsy allows the detection of specific nucleic acids in body fluids and it has particularly benefited from NGS and quantitative PCR approaches, partially overcoming the limit of tumor heterogeneity present in tissue biopsies $(195,200)$. Application of those analyses to blood samples has clear advantages, by allowing multiple and consecutive measurements to follow disease recurrence and clinical management outcomes. The National Institute of Health (NIH) has classified bio-markers into three categories for diagnosis and/or clinical applications (201): (i) Type 0 markers are 'indicators of the natural history of disease'. They can directly or indirectly correlate with diagnosis, prognosis, and outcome of the disease. (ii) Type I markers 'describe the effects of an intervention in accordance with the mechanism of action of the drug' and reflect the general efficacy of treatment through a specific mechanism. Finally, (iii) Type II markers can be used as surrogates for tumor functionality or clinical endpoints (e.g., PFS is often considered 
for GEP-NENs) (194). In addition, regarding the blood based multianalyte tests (mRNA transcripts, i.e., NETest), the Food and Drug Administration provides guidelines for in vitro diagnostic (IVD) tools development. Indeed, FDA defines as IVD "any reagent, instrument, and/or system intended for use in diagnosis of disease or other conditions, including a determination of the state of health, in order to cure, mitigate, treat, or Liquid biomarkers include circulating cell-free DNA (cfDNA), circulating tumor cells (CTCs), small-non-coding molecules, as microRNAs (miRNAs) or long non-coding RNAs (lncRNA), blood transcripts (e.g., NETest) and proteins (Table 4).

The role of cfDNA in PanNENs is debated. CNV analysis of circulating cfDNA mirrors the presence of tumor-specific genetic alterations of PanNEN cells (59). Nevertheless, the prognostic value of cfDNA harboring $R B 1$ and TP53 mutations, typically found in NECs, has not met a consensus yet and it is still under investigation. Similarly genetic alterations affecting ATRX/DAXX and MEN-1 recently found in a subgroup of PanNETs with poor prognosis are not detected yet in cfDNA with a prognostic role $(60,124,204)$.

The prognostic significance of CTCs is uncertain and reports about them in NENs are conflicting. Indeed, some studies associate CTCs increase and bone metastasis in NENs (205), whereas others highlight CTCs low sensitivity for PanNENs (84). At present, the 2016 Delphic consensus on circulating biomarkers in NENs has defined CTCs as a non-reliable marker, due to technical limitations in evaluating their number and phenotype.

Circulating miRNAs are more stable than mRNAs in biofluids and are largely explored as prognostic and/or predictive biomarkers in NEN patients $(58,202)$. Accordingly, several studies have produced signatures of circulating miRNAs associated with PanNEN tissue expression although few reporting prognostic power in PanNENs. Among those miR-21, miR-642, miR-210, miR-196a, miR-96, miR-182, miR-183, and miR-200 are the best characterized $(121,206-208)$. In addition, a set of 10 miRNAs (miR-125a,-99a,-99b,-125b-1,-342,$130 \mathrm{a},-132,-129-2$, and $-125 \mathrm{~b}-2$ ) has been found to distinguish
PanNETs from NEC, whereas miR-204 over-expression resulted to cluster insulinomas (209). Moreover, mir-21 overexpression, which affects PI3K/mTOR pathway via PTEN, has been shown to correlate with higher Ki-67 percentage and liver metastasis in PanNENs (209). Another study reported overexpression of miR-196a as an independent predictor of earlier recurrence, also associated with grade, stage, and lymphatic spread at diagnosis (208). Interestingly, despite the paucity of available preclinical models for NET disease, a metastasis-like (MLP) murine miR-signature (miR-23b,-24-1,-24-2,-27b,-132,137,-181a1, and-181a2) has been detected and interestingly, it has also found to be overexpressed in about $65 \%$ of human PanNETs (188).

LncRNAs can promote angiogenesis, metastasis, and tumor suppressors escape (210-213). The role of lncRNA in PanNENs remains poorly explored in detail yet and most studies investigate their correlation with MEN1 gene-encoding "menin" protein in PanNETs. Modali et al., describe lncRNA Meg3 (maternally expressed gene) as tumor-suppressor in PanNEN cells. PanNENs which produce Menin can activate $\mathrm{Meg} 3$. Meg3 downregulates $c$-Met affecting cell proliferation, migration and invasion in insulinoma. Indeed, $\mathrm{Meg} 3$ and c-MET levels are described to be inversely correlated, both in MEN1-associated PanNENs and sporadic insulinomas. In a recently published paper, Ji et al. found a significant difference in lncRNA and mRNA expression between pNEN tumors and adjacent normal tissues (214).

\section{Blood Transcripts (mRNA) - The NETest}

The NETest is a PCR-based multianalyte test built on tissue and peripheral blood transcripts using a signature of 51 NETs-related genes $(23,215)$. This algorithmic multigene assay was designed and validated specifically for GEP and bronchopulmonary NET diseases $(83,203,216)$. Recent studies showed that NETest serves as diagnostic tool in PanNENs, since it distinguishes NET disease from cancers of different site of origin or non-neoplastic

TABLE 4 | Circulating and tissue molecular biomarkers for PanNENs diagnosis, prognosis and treatment monitoring.

\begin{tabular}{|c|c|c|c|c|c|c|}
\hline \multicolumn{3}{|l|}{ Molecular Markers } & \multirow{2}{*}{$\begin{array}{l}\text { Source } \\
\text { Serum/plasma }\end{array}$} & \multirow{2}{*}{$\begin{array}{l}\text { Level } \\
\text { Increased }\end{array}$} & \multirow{2}{*}{$\begin{array}{l}\text { Clinical use } \\
\text { Related to the PFS and OS }\end{array}$} & \multirow{2}{*}{$\begin{array}{c}\text { References } \\
(202)\end{array}$} \\
\hline Potentially & Circulating Tumor Cells & CTCs & & & & \\
\hline & $\begin{array}{l}\text { Circulating cell free } \\
\text { DNA }\end{array}$ & cfDNA & Serum/plasma & Increased & $\begin{array}{l}\text { Indicative of pancreatic tumor } \\
\text { origin, correlates with primary } \\
\text { tumors mutations (e.g., } \\
\text { ATRX/DAXX) }\end{array}$ & (59) \\
\hline & MicroRNAs & miRNAs & Serum/plasma* & Up/down-regulated & $\begin{array}{l}\text { Diagnostic for site of origin; } \\
\text { prognostic and potentially } \\
\text { predictive for treatment efficacy. }\end{array}$ & (58) \\
\hline
\end{tabular}

PanNENs, Pancreatic Neuroendocrine Neoplasia; PFS, progression-free survival; OS, overall survival. Serum/plasma*: also detected in tumor and healthy tissue. Useful for correlation between circulating and primary tumor markers. 
conditions (e.g., chronic pancreatitis) with $94 \%$ accuracy. Indeed, the NETest resulted much more accurate than current validated CgA measurements, which displayed 56\% overall accuracy (83).

NETest can act as both type 0 and type II biomarker, as it serves both as diagnostic tool and for prognostication on disease status (stable/progressive disease) and treatment efficacy prediction (154, 203, 216-219). Latest meta-analysis by Oberg et al. recently reported a diagnostic accuracy of NETest of 95-96\% with a mean diagnostic odds ratio (DOR) of 5853 , positive likelihood ratio ( $+\mathrm{LR}$ ) of 195, and negative LR of 0.06 in determining the presence of neuroendocrine neoplasia (194). The normalized 51-marker signature is interrogated using 2 separate mathematical algorithmic analyses composing a single score, which is scaled $0-100 \%$ (the NETest score). The updated cut-off of NETest score for diagnosis is 20\% (220225). These data are consistent with the definition of IVD functional ability to establish a diagnosis and determine the presence/absence of the disease. In addition, the NETest was 84.5-85.5\% accurate as a marker of disease status, distinguishing stable disease from progressive disease at the time of the blood draw (219-221, 224-226). These data show the highest (>80\%) concordance with the current Response Evaluation Criteria in Solid Tumors (RECIST) among NET biomarkers, fulfilling NIH proposed cut-off (149). In addition, NETest is observed to be related to functional imaging (e.g., ${ }^{68} \mathrm{Ga}$-somatostatin analogs (SSA)-PET/CT) with $98 \%$ concordance in GEP-NETs, including PanNETs (225). Further studies are required to assess whether a blood test can replace imaging for disease monitoring, thus limiting radiation exposure and potential healthcare costs reduction. NETest is also a valuable marker of natural history of the disease (type 0), with an accuracy of 91.5-97.8\%. In particular, a cut-off of 40 has been demonstrated to distinguish stable disease $(\leq 40 \%)$ and progressive disease ( $\geq 40 \%)$ (227). Finally, NETest can be considered also an interventional/response biomarker with 93.7-97.4\% accuracy, fulfilling type II biomarker requirements of $\mathrm{NIH}$ classification. In particular, a decrease and/or stabilization $(\leq 40 \%)$ of NETest levels correlates with response to PRRT; in contrast with increased levels $(\geq 40 \%)$ during therapy and/or follow up which is suggestive of treatment failure $(219,224,226-228)$. To enforce NETest clinical value as a PRRT-response biomarker, it can be combined with PRRT Predictive Quotient (PPQ) to improve patient stratification (228). PPQ is a blood-based classifier based on specific variants of the NETest gene signature (encompassing growth factor signaling and metabolomic gene expression) (154, 228-230). PPQ has been demonstrated to predict tumor response to internal radiations in broncopulmonary and GEP-NETs (231). PPQ-positive score can predict PRRT-responders with $\sim 95 \%$ accuracy (227). Modlin et al. recently observed that NETest levels significantly decrease after PRRT treatment PPQ positive cohort of "responders," in contrast with increased level of NETest reported in PPQ-negative cohort of "non-reponders." NETtest levels negatively correlate with PPQ positivity $(p<0.0001)(229,230)$. Additionally it has been recenty shown that NETest: (i) high levels $(\geq 40)$ better predict disease recurrence in post-operative PanNETs alone (AUC: 0.82 ) or in combination with RECIST criteria (88\% accuracy) (232); (ii) is very accurate also for GEP and broncopulmonary NEN with $100 \%$ diagnostic accuracy for the latter (233) and (iii) decreased levels after radical resection provide early assessment of surgical efficacy (234).

Very recently, G protein coupled receptor-associated sorting protein-1 (GPRASP-1), known as lysosomal sorting and Beclin2 regulator, has also been proposed as a novel circulating biomarker for neuroendocrine differentiation for PanNENs (235) (Table 5).

\section{CONCLUSIONS}

Currently available biomarkers for PanNENs have limitations and this unmet need hampers early diagnosis, prognosis and follow-up, stratification of patients for therapy selection and post-operative recurrence identification. Assessment of monoanalytes (e.g., CHGA, SYP) is poorly informative about the pathological status and positivity always need to be supported by further investigations. However, the combination of markers, as CHGA/PP, CHGA/NSE, GLUT-1/Ki-67 have been shown to increase specificity and sensitivity, to trace back to the primary tumor site and to better assess the disease aggressiveness, thus helping clinicians in therapeutic decisions. Liquid biopsy represents the new frontier for PanNEN diagnosis and prognosis, since the sensitivity of technologies is constantly increasing,

TABLE 5 | Novel potential biomarkers for PanNENs diagnosis, prognosis and treatment monitoring.

\begin{tabular}{|c|c|c|c|c|c|c|}
\hline Putative markers & & & Source & Level & Clinical use & References \\
\hline \multirow{4}{*}{$\begin{array}{l}\text { Potentially } \\
\text { Prognostic and/or } \\
\text { Predictive }\end{array}$} & Delta-like protein 3 & DLL-3 & $\begin{array}{l}\text { Surgical/endoscopic } \\
\text { biopsy }\end{array}$ & Over-expressed & $\begin{array}{l}\text { Potentially prognostic and } \\
\text { therapeutic target }\end{array}$ & $(236,237)$ \\
\hline & $\begin{array}{l}\text { Tumor-Associated- } \\
\text { Macrophages }\end{array}$ & TAMs & $\begin{array}{l}\text { Surgical/endoscopic } \\
\text { biopsy }\end{array}$ & Increased & Associated to reduced DSS & $(61)$ \\
\hline & $\begin{array}{l}\text { G protein coupled } \\
\text { receptor-associated } \\
\text { sorting protein } 1\end{array}$ & GPRASP-1 & Serum & Down-regulated & $\begin{array}{l}\text { Neuroendocrine } \\
\text { de-differentiation }\end{array}$ & $(235)$ \\
\hline & Glucose transporter 1 & GLUT-1 & $\begin{array}{l}\text { Surgical/endoscopic } \\
\text { biopsy }\end{array}$ & Over-expressed & $\begin{array}{l}\text { Prognostic for higher } \\
\text { metabolism and tumor } \\
\text { aggressiveness }\end{array}$ & (90) \\
\hline
\end{tabular}

PanNENs, Pancreatic Neuroendocrine Neoplasia; GEP-NENs, Gastro-Entero-Pancreatic Neoplasia. 
hence allowing the detection of smaller and smaller amounts of biomarkers with non-invasive procedures. This is leading to earlier diagnosis and more accurate assessment of minimal residual disease after treatment. However, the role of markers such as cfDNA and CTCs is still controversial and requires expensive equipment and well-trained personnel for the analyses. Conversely, the detection of non-coding RNAs, such as miRNAs and lncRNAs is less expensive and more accessible from an economical and a know-how stand-point. Notably, circulating RNAs can not only function as prognostic and/or predictive biomarkers, but also serve as therapeutic targets for tailored approaches, including miRNA replacement. Recently designed clinical trial, SENECA study (NCT03387592) and translational ones as the NET-SEQ study (NCT02586844) and the Royal Marsden PaC-MAn Study (NCT03840460) are at the forefront of this challenge. In particular the Italian SENECA trial focuses on some specific biomarkers on primary tumor tissues and for miRNAs on blood samples while NET-SEQ and PaC-MAN

\section{REFERENCES}

1. Halfdanarson TR, Rabe KG, Rubin J, Petersen GM. Pancreatic neuroendocrine tumors (PNETs): incidence, prognosis and recent trend toward improved survival. Ann Oncol. (2008) 19:1727-33. doi: 10.1093/annonc/mdn351

2. Dasari A, Shen C, Halperin D, Zhao B, Zhou S, Xu Y, et al. Trends in the incidence, prevalence, and survival outcomes in patients with neuroendocrine tumors in the united states. JAMA oncology. (2017) 3:133542. doi: 10.1001/jamaoncol.2017.0589

3. Modlin IM, Öberg K, Chung DC, Jensen RT, de Herder WW, Thakker RV, et al. Gastroenteropancreatic neuroendocrine tumours. Lancet Oncol. (2008) 9:61-72. doi: 10.1016/S1470-2045(07)70410-2

4. Anlauf M, Garbrecht N, Bauersfeld J, Schmitt A, Henopp T, Komminoth P, et al. Hereditary neuroendocrine tumors of the gastroenteropancreatic system. Virchows Arch. (2007) 451 Suppl 1:S29-38. doi: 10.1007/s00428-007-0450-3

5. Falconi M, Eriksson B, Kaltsas G, Bartsch DK, Capdevila J, Caplin $\mathrm{M}$, et al. ENETS consensus guidelines update for the management of patients with functional pancreatic neuroendocrine tumors and nonFunctional pancreatic neuroendocrine tumors. Neuroendocrinology. (2016). 153-171. doi: 10.1159/000443171

6. Modlin IM, Gustafsson BI, Moss SF, Pavel M, Tsolakis AV, Kidd M. Chromogranin a-biological function and clinical utility in neuro endocrine tumor disease. Ann Surg Oncol. (2010) 17:2427-43. doi: 10.1245/s10434-010-1006-3

7. Marx SJ, Simonds WF. Hereditary hormone excess: genes, molecular pathways, and syndromes. Endocr Rev. (2005) 26:615-61. doi: 10.1210/er.2003-0037

8. Swarts DRA, Ramaekers FCS, Speel E-JM. Biochimica et biophysica acta. BBA - Reviews on Cancer. (2012) 1826:25571. doi: 10.1016/j.bbcan.2012.05.001

9. Compton CC, Byrd DR, Garcia-Aguilar J, Kurtzman SH, Olawaiye A, Washington MK. AJCC Cancer Staging Atlas. Berlin: Springer Science \& Business Media (2012).

10. International Agency for Research on Cancer. WHO Classification of Tumours of Endocrine Organs. Lyon: IARC Who Classification of Tum (2017).

11. Choe J, Kim KW, Kim HJ, Kim DW, Kim KP, Hong S-M, et al. What is new in the 2017 world health organization classification and 8th american joint committee on cancer staging system for pancreatic neuroendocrine neoplasms? Korean J Radiol. (2019) 20:5-17. doi: 10.3348/kjr.2018. 0040 studies are investigating the molecular alterations in intestinal and pancreatic neuroendocrine tumors both in tissue and blood samples. Both studies leverage on NGS sensitivity to discover novel DNA/RNA-based biomarkers from liquid biopsies of NEN patients. We believe those trials will pioneer the identification of the next generation biomarkers for PanNENs.

\section{AUTHOR CONTRIBUTIONS}

$\mathrm{MB}$ wrote the review, prepared figures. FN helped in preparing the figures. SS, $\mathrm{AB}$, and TI provided supervision on the topic. GS edited and commented on the manuscript. IG edited the manuscript. MM conceived and wrote the review.

\section{ACKNOWLEDGMENTS}

We thank Alicja M. Gruszka for her help in proofreading of this manuscript.

12. O’Toole D, Kianmanesh R, Caplin M. ENETS 2016 consensus guidelines for the management of patients with digestive neuroendocrine tumors: an update. Neuroendocrinology. (2016) 103:117-8. doi: 10.1159/000 443169

13. Inzani F, Petrone G, Rindi G. The new world health organization classification for pancreatic neuroendocrine neoplasia. Endocrinol Metab Clin North Am. (2018) 47:463-70. doi: 10.1016/j.ecl.2018.04.008

14. Rindi G, Klöppel G, Couvelard A, Komminoth P, Körner M, Lopes JM, et al. TNM staging of midgut and hindgut (neuro) endocrine tumors: a consensus proposal including a grading system. Virchows Arch. (2007). 757-62. doi: 10.1007/s00428-007-0452-1

15. Turner GB, Johnston BT, McCance DR, McGinty A, Watson RGP, Patterson CC, et al. Circulating markers of prognosis and response to treatment in patients with midgut carcinoid tumours. Gut. (2006) 55:158691. doi: 10.1136/gut.2006.092320

16. Modlin IM, Gustafsson BI, Pavel M, Svejda B, Lawrence B, Kidd M. A nomogram to assess small-intestinal neuroendocrine tumor ("carcinoid") survival. Neuroendocrinology. (2010) 92:143-57. doi: 10.1159/000319784

17. Pape U-F, Böhmig M, Berndt U, Tiling N, Wiedenmann B, Plöckinger U. Survival and clinical outcome of patients with neuroendocrine tumors of the gastroenteropancreatic tract in a german referral center. Ann N Y Acad Sci. (2004) 1014:222-33. doi: 10.1196/annals.1294.025

18. Veenendaal LM, Borel Rinkes IHM, Lips CJM, van Hillegersberg R. Liver metastases of neuroendocrine tumours; early reduction of tumour load to improve life expectancy. World J Surg Oncol. (2006) 4:35. doi: 10.1186/1477-7819-4-35

19. Hofland J, Zandee WT, de Herder WW. Role of biomarker tests for diagnosis of neuroendocrine tumours. Nat Rev Endocrinol. (2018) 14:656-9. doi: 10.1038/s41574-018-0082-5

20. O’Toole D, Grossman A, Gross D, Delle Fave G, Barkmanova J, O'Connor J, et al. ENETS consensus guidelines for the standards of care in neuroendocrine tumors: biochemical markers. Neuroendocrinology. (2017).194-202. doi: 10.1159/000225948

21. Niederle B, Pape U-F, Costa F, Gross D, Kelestimur F, Knigge U, et al. ENETS consensus guidelines update for neuroendocrine neoplasms of the jejunum and ileum. Neuroendocrinology. (2016). 125-138. doi: 10.1159/000443170

22. Nobels FR, Kwekkeboom DJ, Coopmans W, Schoenmakers CH, Lindemans J, De Herder WW, et al. Chromogranin a as serum marker for neuroendocrine neoplasia: comparison with neuron-specific enolase and the alpha-subunit of glycoprotein hormones. J Clin Endocrinol Metab. (1997) 82:2622-8. doi: 10.1210/jcem.82.8.4145

23. Herrera-Martínez AD, Hofland LJ, Gálvez Moreno MA, Castaño JP, de Herder WW, Feelders RA. Neuroendocrine neoplasms: current and potential 
diagnostic, predictive and prognostic markers. Endocr Relat Cancer. (2019) 26:R157-R79. doi: 10.1530/ERC-18-0354

24. Sansone A, Lauretta R, Vottari S, Chiefari A, Barnabei A, Romanelli F, et al. Specific and non-Specific biomarkers in neuroendocrine gastroenteropancreatic tumors. Cancers (Basel). (2019) 11:11081113. doi: $10.3390 /$ cancers 11081113

25. Ramage JK, Davies AHG, Ardill J, Bax N, Caplin M, Grossman $\mathrm{A}$, et al. Guidelines for the management of gastroenteropancreatic neuroendocrine (including carcinoid) tumours. Gut. (2005) 54(Suppl. 4):iv1-16. doi: 10.1136/gut.2004.053314

26. Lokich JJ, Ganda OP, O’Hara CJ, Warren KW, Moertel CG, Klee G. Alphafetoprotein associated with islet cell tumors. Am J Clin Oncol. (1987) 10:1335. doi: 10.1097/00000421-198704000-00046

27. Shibata C, Kakyo M, Kinouchi M, Tanaka N, Miura K, Naitoh T, et al. Criteria for the glucagon provocative test in the diagnosis of gastrinoma. Surg Today. (2013) 43:1281-5. doi: 10.1007/s00595-012-0334-2

28. Öberg K, Couvelard A, Delle Fave G, Gross D, Grossman A, Jensen RT, et al. ENETS consensus guidelines for standard of care in neuroendocrine tumours: biochemical markers. Neuroendocrinology. (2017) 105:20111. doi: 10.1159/000472254

29. Öberg K, Knigge U, Kwekkeboom D, Perren A, ESMO Guidelines Working Group. Neuroendocrine gastro-entero-pancreatic tumors: ESMO Clinical Practice Guidelines for diagnosis, treatment and follow-up. Ann Oncol. (2012) 23 Suppl 7:vii124-30. doi: 10.1093/annonc/mds295

30. Walter T, Chardon L, Chopin-laly X, Raverot V, Caffin A-G, Chayvialle J$\mathrm{A}$, et al. Is the combination of chromogranin a and pancreatic polypeptide serum determinations of interest in the diagnosis and follow-up of gastroentero-pancreatic neuroendocrine tumours? Eur J Cancer. (2012) 48:176673. doi: 10.1016/j.ejca.2011.11.005

31. Tony JC. The chromogranin-secretogranin family. N Engl J Med. (2003) 348:2579-80. doi: 10.1056/NEJMra021405

32. Kanakis G, Kaltsas G. Biochemical markers for gastroenteropancreatic neuroendocrine tumours (GEP-NETs). Best Pract Res Clin Gastroenterol. (2012) 26:791-802. doi: 10.1016/j.bpg.2012.12.006

33. Woltering EA, Hilton RS, Zolfoghary CM, Thomson J, Zietz S, Go VLW, et al. Validation of serum versus plasma measurements of chromogranin a levels in patients with carcinoid tumors: lack of correlation between absolute chromogranin a levels and symptom frequency. Pancreas. (2006) 33:250-4. doi: 10.1097/01.mpa.0000235302.73615.d4

34. Modlin IM, Bodei L, Kidd M. Neuroendocrine tumor biomarkers: from monoanalytes to transcripts and algorithms. Best Pract Res Clin Endocrinol Metab. (2016) 30:59-77. doi: 10.1016/j.beem.2016.01.002

35. Wang Y-H, Yang Q-C, Lin Y, Xue L, Chen M-H, Chen J. Chromogranin a as a marker for diagnosis, treatment, and survival in patients with gastroenteropancreatic neuroendocrine neoplasm. Medicine (Baltimore). (2014) 93:e247. doi: 10.1097/MD.0000000000000247

36. Lawrence B, Gustafsson BI, Kidd M, Pavel M, Svejda B, Modlin IM. The clinical relevance of chromogranin a as a biomarker for gastroenteropancreatic neuroendocrine tumors. Endocrinol Metab Clin North Am. (2011) 40:111-34- viii. doi: 10.1016/j.ecl.2010.12.001

37. Grimaldi F, Fazio N, Attanasio R, Frasoldati A, Papini E, Angelini $\mathrm{F}$, et al. Italian association of clinical endocrinologists (AME) position statement: a stepwise clinical approach to the diagnosis of gastroenteropancreatic neuroendocrine neoplasms. J Endocrinol Invest. (2014) 37:875-909. doi: 10.1007/s40618-014-0119-0

38. Vinik AI, Silva MP, Woltering EA, Woltering G, Go VLW, Warner R, et al. Biochemical testing for neuroendocrine tumors. Pancreas. (2009) 38:87689. doi: 10.1097/MPA.0b013e3181bc0e77

39. van Adrichem RCS, Kamp K, Vandamme T, Peeters M, Feelders RA, De Herder WW. Serum neuron-specific enolase level is an independent predictor of overall survival in patients with gastroenteropancreatic neuroendocrine tumors. Ann Oncol. (2016) 27:746-7. doi: 10.1093/annonc/mdv626

40. Baudin E, Gigliotti A, Ducreux M, Ropers J, Comoy E, Sabourin JC, et al. Neuron-specific enolase and chromogranin a as markers of neuroendocrine tumours. Br J Cancer. (1998) 78:1102-7. doi: 10.1038/bjc.1998.635

41. Yao JC, Pavel M, Phan AT, Kulke MH, Hoosen S, St. Peter J, et al. Chromogranin a and neuron-specific enolase as prognostic markers in patients with advanced pNET treated with everolimus. J Clin Endocrinol Metab. (2011) 96:3741-9. doi: 10.1210/jc.2011-0666

42. Panzuto F, Severi C, Cannizzaro R, Falconi M, Angeletti S, Pasquali A, et al. Utility of combined use of plasma levels of chromogranin a and pancreatic polypeptide in the diagnosis of gastrointestinal and pancreatic endocrine tumors. J Endocrinol Invest. (2004) 27:6-11. doi: 10.1007/bf03350903

43. Kulke $\mathrm{MH}$, Shah $\mathrm{MH}$, Benson AB, Bergsland E, Berlin JD, Blaszkowsky LS, et al. Neuroendocrine tumors, version 1.2015. J Natl Compr Canc Netw. (2015) 13:78-108. doi: 10.6004/jnccn.2015. 0011

44. Metz DC, Jensen RT. Gastrointestinal neuroendocrine tumors: pancreatic endocrine tumors. Gastroenterology. (2008) 135:146992. doi: 10.1053/j.gastro.2008.05.047

45. Yu R. Radiotherapy: radioactive somatostatin analog therapy against carcinoids. Nature Publishing Group. (2010) 6:42830. doi: $10.1038 /$ nrendo. 2010.94

46. Ardill JES, Erikkson B. The importance of the measurement of circulating markers in patients with neuroendocrine tumours of the pancreas and gut. Endocr Relat Cancer. (2003) 10:459-62. doi: 10.1677/erc.0.0100459

47. Jung JY, Kim YJ, Kim HM, Kim HJ, Park SW, Song SY, et al. Hepatoid carcinoma of the pancreas combined with neuroendocrine carcinoma. Gut Liver. (2010) 4:98-102. doi: 10.5009/gnl.2010.4.1.98

48. McIntire KR, Waldmann TA, Moertel CG, Go VL. Serum alpha-fetoprotein in patients with neoplasms of the gastrointestinal tract. Cancer Res. (1975) 35:991-6.

49. Shah T, Srirajaskanthan R, Bhogal M, Toubanakis C, Meyer T, Noonan A, et al. Alpha-fetoprotein and human chorionic gonadotrophin-beta as prognostic markers in neuroendocrine tumour patients. Br J Cancer. (2008) 99:72-7. doi: 10.1038/sj.bjc.6604428

50. Kyriakopoulos G, Mavroeidi V, Chatzellis E, Kaltsas GA, Alexandraki KI. Histopathological, immunohistochemical, genetic and molecular markers of neuroendocrine neoplasms. Ann Transl Med. (2018) 6:252. doi: 10.21037/atm.2018.06.27

51. de Herder WW, Niederle B, Scoazec J-Y, Pauwels S, Klöppel G, Falconi $\mathrm{M}$, et al. Well-differentiated pancreatic tumor/carcinoma: insulinoma. Neuroendocrinology. (2006). 183-188. doi: 10.1159/000098010

52. Eldor R, Glaser B, Fraenkel M, Doviner V, Salmon A, Gross DJ. Glucagonoma and the glucagonoma syndrome - cumulative experience with an elusive endocrine tumour. Clin Endocrinol. (2011) 74:5938. doi: 10.1111/j.1365-2265.2011.03967.x

53. Low MJ. Clinical endocrinology and metabolism. The somatostatin neuroendocrine system: physiology and clinical relevance in gastrointestinal and pancreatic disorders. Best Pract Res Clin Endocrinol Metab. (2004) 18:607-22. doi: 10.1016/j.beem.2004.08.005

54. Perry RR, Vinik AI. Clinical review 72: diagnosis and management of functioning islet cell tumors. J Clin Endocrinol Metab. (1995) 80:22738. doi: 10.1210/jcem.80.8.7629220

55. Lloyd RV. Immunohistochemical markers of endocrine/Neuroendocrine tumors. J Histotechnol. (2013) 22:231-7. doi: 10.1002/path.1711630405

56. Doglioni C, Gambacorta M, Zamboni G, Coggi G, Viale G. Immunocytochemical localization of progesterone receptors in endocrine cells of the human pancreas. Am J Pathol. (1990) 137:999-1005.

57. Bellizzi AM. Assigning site of origin in metastatic neuroendocrine neoplasms: a clinically significant application of diagnostic immunohistochemistry. Adv Anat Pathol. (2013) 20:285314. doi: 10.1097/PAP.0b013e3182a2dc67

58. Butz H, Patócs A. MicroRNAs in endocrine tumors. EJIFCC. (2019) 30:14664.

59. Boons G, Vandamme T, Peeters M, Beyens M, Driessen A, Janssens K, et al. Cell-Free dNA from metastatic pancreatic neuroendocrine tumor patients contains tumor-Specific mutations and copy number variations. Front Oncol. (2018) 8:467. doi: 10.3389/fonc.2018.00467

60. Park JK, Paik WH, Lee K, Ryu JK, Lee SH, Kim Y-T. DAXX/ATRX and mEN1 genes are strong prognostic markers in pancreatic neuroendocrine tumors. Oncotarget. (2017) 8:49796-9806. doi: 10.18632/oncotarget. 17964

61. Francisco-Cruz A, Uraoka N, Liu S, Parra ER, Solis LM, Mino $\mathrm{B}$, et al. Abstract 4576: study of the immune contexture in 
advanced pancreatic neuroendocrine tumors reveals tumor-associated macrophages as promoters of poor survival. Cancer Res. (2019) 79:4576. doi: 10.1158/1538-7445.AM2019-4576

62. Öberg K, Krenning E, Sundin A, Bodei L, Kidd M, Tesselaar M, et al. A delphic consensus assessment: imaging and biomarkers in gastroenteropancreatic neuroendocrine tumor disease management. Endocr Connect. (2016) 5:174-87. doi: 10.1530/EC-16-0043

63. Erickson LA, Lloyd RV. Practical markers used in the diagnosis of endocrine tumors. Adv Anat Pathol. (2004) 11:175-89. doi: 10.1097/01.pap.0000131824.7 7317.a7

64. Chai SM, Brown IS, Kumarasinghe MP. Gastroenteropancreatic neuroendocrine neoplasms: selected pathology review and molecular updates. Histopathology. (2018) 72:153-67. doi: 10.1111/his.13367

65. Koo J, Mertens RB, Mirocha JM, Wang HL, Dhall D. Value of islet 1 and pAX8 in identifying metastatic neuroendocrine tumors of pancreatic origin. Mod Pathol. (2012) 25:893-901. doi: 10.1038/modpathol.2012.34

66. Arnason T, Sapp HL, Barnes PJ, Drewniak M, Abdolell M, Rayson D. Immunohistochemical expression and prognostic value of ER, PR and HER2/neu in pancreatic and small intestinal neuroendocrine tumors. Neuroendocrinology. (2011) 93:249-58. doi: 10.1159/000326820

67. Khan JA, Bellance C, Guiochon-Mantel A, Lombès M, Loosfelt H. Differential regulation of breast cancer-associated genes by progesterone receptor isoforms $\mathrm{pRA}$ and $\mathrm{pRB}$ in a new bi-inducible breast cancer cell line. PLoS ONE. (2012) 7:e45993. doi: 10.1371/journal.pone.0045993

68. Saito S, Ito K, Nagase S, Suzuki T, Akahira J-I, Okamura K, et al. Progesterone receptor isoforms as a prognostic marker in human endometrial carcinoma. Cancer Sci. (2006) 97:1308-14. doi: 10.1111/j.1349-7006.2006.00332.x

69. Roy PG, Thompson AM. Cyclin d1 and breast cancer. Breast. (2006) 15:71827. doi: $10.1016 /$ j.breast.2006.02.005

70. Yazdani S, Kasajima A, Ogata H, Felizola SJA, Nakamura Y, Onodera Y, et al. Progesterone receptor isoforms $\mathrm{a}$ and $\mathrm{b}$ in pancreatic neuroendocrine tumor. Neuroendocrinology. (2015) 101:309-20. doi: 10.1159/000381455

71. Jakobsen A-M, Ahlman H, Kölby L, Abrahamsson J, Fischer-Colbrie R, Nilsson O. NESP55, a novel chromogranin-like peptide, is expressed in endocrine tumours of the pancreas and adrenal medulla but not in ileal carcinoids. Br J Cancer. (2003) 88:1746-54. doi: 10.1038/sj.bjc.6600924

72. Turque N, Plaza S, Radvanyi F, Carriere C, Saule S. Pax-QNR/Pax-6, a paired box- and homeobox-containing gene expressed in neurons, is also expressed in pancreatic endocrine cells. Mol Endocrinol. (1994) 8:92938. doi: 10.1210/mend.8.7.7984154

73. Sangoi AR, Ohgami RS, Pai RK, Beck AH, McKenney JK, Pai RK. PAX8 expression reliably distinguishes pancreatic well-differentiated neuroendocrine tumors from ileal and pulmonary well-differentiated neuroendocrine tumors and pancreatic acinar cell carcinoma. Mod Pathol. (2011) 24:412-24. doi: 10.1038/modpathol.2010.176

74. Gurevich LE, Proshchina AE, Voronkova IA, Ashevskaya VE, Korosteleva PA, Dolzhansky OV. [Differential diagnostic value of the expression of the transcription factor $\mathrm{pDX}-1$ in neuroendocrine and non-neuroendocrine tumors of the pancreas and other organs]. Arkh Patol. (2019) 81:1121. doi: 10.17116/patol20198105111

75. Srivastava A, Hornick JL. Immunohistochemical staining for cDX-2, pDX-1, nESP-55, and tTF-1 can help distinguish gastrointestinal carcinoid tumors from pancreatic endocrine and pulmonary carcinoid tumors. Am J Surg Pathol. (2009) 33:626-32. doi: 10.1097/PAS.0b013e31818d7d8b

76. Long KB, Srivastava A, Hirsch MS, Hornick JL. PAX8 expression in well-differentiated pancreatic endocrine tumors: correlation with clinicopathologic features and comparison with gastrointestinal and pulmonary carcinoid tumors. Am J Surg Pathol. (2010) 34:723-9. doi: 10.1097/PAS.0b013e3181da0a20

77. Koo J, Zhou X, Moschiano E, De Peralta-Venturina M, Mertens RB, Dhall D. The immunohistochemical expression of islet 1 and pAX8 by rectal neuroendocrine tumors should be taken into account in the differential diagnosis of metastatic neuroendocrine tumors of unknown primary origin. Endocr Pathol. (2013) 24:184-90. doi: 10.1007/s12022-0139264-9

78. Papotti M, Bongiovanni M, Volante M, Allì E, Landolfi S, Helboe L, et al. Expression of somatostatin receptor types 1-5 in 81 cases of gastrointestinal and pancreatic endocrine tumors. A correlative immunohistochemical and reverse-transcriptase polymerase chain reaction analysis. Virchows Arch. (2002) 440:461-75. doi: 10.1007/s00428-002-0609-x

79. Carideo L, Prosperi D, Panzuto F, Magi L, Pratesi MS, Rinzivillo M, et al. Role of combined [68Ga] Ga-DOTA-SST analogues and [18F]FDG pET/CT in the management of gEP-NENs: a systematic review. J Clin Med. (2019) 8:32. doi: $10.3390 / \mathrm{jcm} 8071032$

80. Wang Y, Wang $\mathrm{W}$, Jin $\mathrm{K}$, Fang $\mathrm{C}$, Lin $\mathrm{Y}$, Xue L, et al. Somatostatin receptor expression indicates improved prognosis in gastroenteropancreatic neuroendocrine neoplasm, and octreotide longacting release is effective and safe in chinese patients with advanced gastroenteropancreatic neuroendocrine tumors. Oncol Lett. (2017) 13:1165-74. doi: 10.3892/ol.2017.5591

81. Liverani C, Bongiovanni A, Mercatali L, Foca F, Pieri F, De Vita A, et al. Grading of neuroendocrine carcinomas: correlation of $68 \mathrm{Ga}-$ PET/CT scan with tissue biomarkers. Dis Markers. (2018) 2018:18. doi: 10.2214/AJR.17.18417

82. Kaemmerer D, Wirtz RM, Fischer EK, Hommann M, Sänger J, Prasad V, et al. Analysis of somatostatin receptor $2 \mathrm{~A}$ immunohistochemistry, rT-qPCR, and in vivo $\mathrm{pET} / \mathrm{CT}$ data in patients with pancreatic neuroendocrine neoplasm. Pancreas. (2015) 44:648-54. doi: 10.1097/MPA.0000000000000316

83. Modlin IM, Kidd M, Bodei L, Drozdov I, Aslanian H. The clinical utility of a novel blood-based multi-transcriptome assay for the diagnosis of neuroendocrine tumors of the gastrointestinal tract. Am J Gastroenterol. (2015) 110:1223-32. doi: 10.1038/ajg.2015.160

84. Öberg K, Modlin IM, De Herder W, Pavel M, Klimstra D, Frilling A, et al. Consensus on biomarkers for neuroendocrine tumour disease. Lancet Oncol. (2015) 16:e435-e46. doi: 10.1016/S1470-2045(15)00186-2

85. Clavo AC, Brown RS, Wahl RL. Fluorodeoxyglucose uptake in human cancer cell lines is increased by hypoxia. J Nucl Med. (1995) 36:1625-32.

86. Reis H, Tschirdewahn S, Szarvas T, Rübben H, Schmid KW, Grabellus F. Expression of gLUT1 is associated with increasing grade of malignancy in non-invasive and invasive urothelial carcinomas of the bladder. Oncol Lett. (2011) 2:1149-53. doi: 10.3892/ol.2011.394

87. Wincewicz A, Sulkowska M, Koda M, Sulkowski S. Clinicopathological significance and linkage of the distribution of hIF-1alpha and gLUT1 in human primary colorectal cancer. Pathol Oncol Res. (2007) 13:1520. doi: $10.1007 / \mathrm{bf} 02893436$

88. Ozbudak IH, Shilo K, Tavora F, Rassaei N, Chu W-S, Fukuoka $\mathrm{J}$, et al. Glucose transporter-1 in pulmonary neuroendocrine carcinomas: expression and survival analysis. Mod Pathol. (2009) 22:633-8. doi: 10.1038/modpathol.2009.6

89. Fujino M, Aishima S, Shindo K, Oda Y, Morimatsu K, Tsutsumi K, et al. Expression of glucose transporter-1 is correlated with hypoxia-inducible factor $1 \alpha$ and malignant potential in pancreatic neuroendocrine tumors. Oncol Lett. (2016) 12:3337-43. doi: 10.3892/ol.2016.5092

90. Binderup T, Knigge UP, Federspiel B, Sommer P, Hasselby JP, Loft A, et al. Gene expression of glucose transporter 1 (GLUT1), hexokinase 1 and hexokinase 2 in gastroenteropancreatic neuroendocrine tumors: correlation with f-18-fluorodeoxyglucose positron emission tomography and cellular proliferation. Diagnostics (Basel). (2013) 3:372-84. doi: 10.3390/diagnostics3040372

91. Severi S, Nanni O, Bodei L, Sansovini M, Ianniello A, Nicoletti S, et al. Role of 18FDG pET/CT in patients treated with 177Lu-DOTATATE for advanced differentiated neuroendocrine tumours. Eur J Nucl Med. (2013) 40:881-8. doi: 10.1007/s00259-013-2369-z

92. Bocchini M, Mazza M, Foca F, Nicolini F, Calogero RA, Severi S, et al. 1385PDNew circulating biomarkers in gastroentero-pancreatic-neuroendocrine-tumours. Annonc. (2019) 30. doi: $10.1093 /$ annonc/mdz256.005

93. Schalper KA. PD-L1 expression and tumor-infiltrating lymphocytes: revisiting the antitumor immune response potential in breast cancer. Oncoimmunology. (2014) 3:e29288. doi: 10.4161/onci.29288

94. Cavalcanti E, Armentano R, Valentini AM, Chieppa M, Caruso ML. Role of $\mathrm{pD}-\mathrm{L} 1$ expression as a biomarker for gEP neuroendocrine neoplasm grading. Cell Death Dis. (2017) 8:e3004. doi: 10.1038/cddis.2017.401

95. Pinato DJ, Vallipuram A, Evans JS, Wong C, Zhang H, Brown $M$, et al. Programmed cell death ligands expression 
drives immune tolerogenesis across the diverse subtypes of neuroendocrine tumours. Neuroendocrinology. (2020) doi: 10.1159/0005 06745

96. Xie H, Isse K, Sun Y, Ramoth J, French DM, Saunders LR, et al. Abstract 3171: delta-like protein 3 expression in merkel cell carcinoma. Cancer Res. (2019) 79:3171. doi: 10.1158/1538-7445.AM2019-3171

97. Saunders LR, Bankovich AJ, Anderson WC, Aujay MA, Bheddah S, Black $\mathrm{K}$, et al. A dLL3-targeted antibody-drug conjugate eradicates high-grade pulmonary neuroendocrine tumor-initiating cells in vivo. Sci Transl Med. (2015) 7:302ra136. doi: 10.1126/scitranslmed.aac9459

98. Spino M, Kurz SC, Chiriboga L, Serrano J, Zeck B, Sen N, et al. Cell surface notch ligand dLL3 is a therapeutic target in isocitrate dehydrogenase-mutant glioma. Clin Cancer Res. (2019) 25:1261-71. doi: 10.1158/1078-0432.CCR-18-2312

99. Koshkin VS, Garcia JA, Reynolds J, Elson P, Magi-Galluzzi C, McKenney JK, et al. Transcriptomic and protein analysis of smallcell bladder cancer (SCBC) identifies prognostic biomarkers and dLL3 as a relevant therapeutic target. Clin Cancer Res. (2019) 25:210-21. doi: 10.1158/1078-0432.CCR-18-1278

100. George J, Walter V, Peifer M, Alexandrov LB, Seidel D, Leenders F, et al. Integrative genomic profiling of large-cell neuroendocrine carcinomas reveals distinct subtypes of high-grade neuroendocrine lung tumors. Nature Communications. (2018) 9:1048. doi: 10.1038/s41467-018-03099-x

101. Näthke I. Cytoskeleton out of the cupboard: colon cancer and cytoskeletal changes induced by loss of aPC. Nat Rev Cancer. (2006) 6:96774. doi: $10.1038 / \mathrm{nrc} 2010$

102. Liu B, Tang LH, Liu Z, Mei M, Yu R, Dhall D, et al. $\alpha$-Internexin: a novel biomarker for pancreatic neuroendocrine tumor aggressiveness. J Clin Endocrinol Metab. (2014) 99:E786-95. doi: 10.1210/jc.2013-2874

103. Schimmack S, Lawrence B, Svejda B, Alaimo D, Schmitz-Winnenthal $\mathrm{H}$, Fischer L, et al. The clinical implications and biologic relevance of neurofilament expression in gastroenteropancreatic neuroendocrine neoplasms. Cancer. (2012) 118:2763-75. doi: 10.1002/cncr.26592

104. Grabowski P, Griss S, Arnold CN, Hörsch D, Göke R, Arnold R, et al. Nuclear survivin is a powerful novel prognostic marker in gastroenteropancreatic neuroendocrine tumor disease. Neuroendocrinology. (2005) 81:1-9. doi: 10.1159/000084892

105. Korse CM, Taal BG, Bonfrer JMG, Vincent A, van Velthuysen ML, Baas P. An elevated progastrin-releasing peptide level in patients with welldifferentiated neuroendocrine tumours indicates a primary tumour in the lung and predicts a shorter survival. Ann Oncol. (2011) 22:262530. doi: 10.1093/annonc/mdr007

106. Fotouhi O, Kjellin H, Larsson C, Hashemi J, Barriuso J, Juhlin CC, et al. Proteomics suggests a role for aPC-Survivin in response to somatostatin analog treatment of neuroendocrine tumors. J Clin Endocrinol Metab. (2016) 101:3616-27. doi: 10.1210/jc.2016-2028

107. Edfeldt K, Daskalakis K, Bäcklin C, Norlén O, Tiensuu Janson E, Westin $\mathrm{G}$, et al. DcR3, tFF3, and midkine are novel serum biomarkers in small intestinal neuroendocrine tumors. Neuroendocrinology. (2017) 105:17081. doi: 10.1159/000452891

108. Schüller M, Jenne D, Voltz R. The human pNMA family: novel neuronal proteins implicated in paraneoplastic neurological disease. J Neuroimmunol. (2005) 169:172-6. doi: 10.1016/j.jneuroim.2005.08.019

109. Cui T, Hurtig M, Elgue G, Li S-C, Veronesi G, Essaghir A, et al. Paraneoplastic antigen ma2 autoantibodies as specific blood biomarkers for detection of early recurrence of small intestine neuroendocrine tumors. PLoS ONE. (2010) 5:e16010. doi: 10.1371/journal.pone.00 16010

110. Mihaly SR, Ninomiya-Tsuji J, Morioka S. TAK1 control of cell death. Cell Death Differ. (2014) 21:1667-76. doi: 10.1038/cdd.2014.123

111. Obexer P, Ausserlechner MJ. X-linked inhibitor of apoptosis protein - a critical death resistance regulator and therapeutic target for personalized cancer therapy. Front Oncol. (2014) 4:197. doi: 10.3389/fonc.2014.00197

112. Cingarlini S, Bonomi M, Corbo V, Scarpa A, Tortora G. Profiling mTOR pathway in neuroendocrine tumors. Target Oncol. (2012) 7:1838. doi: 10.1007/s11523-012-0226-9

113. Augeri DJ, Langenfeld E, Castle M, Gilleran JA, Langenfeld J. Inhibition of bMP and of tGF $\beta$ receptors downregulates expression of xIAP and tAK1 leading to lung cancer cell death. Mol Cancer. (2016) 15:27. doi: 10.1186/s12943-016-0511-9

114. Yap TA, Yan L, Patnaik A, Fearen I, Olmos D, Papadopoulos K, et al. First-in-man clinical trial of the oral pan-AKT inhibitor mK-2206 in patients with advanced solid tumors. J Clin Oncol. (2011) 29:468895. doi: 10.1200/JCO.2011.35.5263

115. Schwartzentruber J, Korshunov A, Liu X-Y, Jones DTW, Pfaff E, Jacob K, et al. Driver mutations in histone h3.3 and chromatin remodeling genes in paediatric glioblastoma. Nature. (2012) 482:22631. doi: $10.1038 /$ nature 10833

116. Heaphy CM, de Wilde RF, Jiao Y, Klein AP, Edil BH, Shi C, et al. Altered telomeres in tumors with aTRX and dAXX mutations. Science. (2011) 333:425. doi: 10.1126/science. 1207313

117. Marinoni I, Kurrer AS, Vassella E, Dettmer M, Rudolph T, Banz V, et al. Loss of dAXX and aTRX are associated with chromosome instability and reduced survival of patients with pancreatic neuroendocrine tumors. Gastroenterology. (2014) 146:453-60.e5. doi: 10.1053/j.gastro.2013.10.020

118. Kim JY, Brosnan-Cashman JA, An S, Kim SJ, Song K-B, Kim M-S, et al. Alternative lengthening of telomeres in primary pancreatic neuroendocrine tumors is associated with aggressive clinical behavior and poor survival. Clin Cancer Res. (2017) 23:1598-606. doi: 10.1158/1078-0432.CCR-16-1147

119. Jiao Y, Shi C, Edil BH, de Wilde RF, Klimstra DS, Maitra A, et al. DAXX/ATRX, mEN1, and mTOR pathway genes are frequently altered in pancreatic neuroendocrine tumors. Science. (2011) 331:1199203. doi: 10.1126/science. 1200609

120. Dogeas E, Karagkounis G, Heaphy CM, Hirose K, Pawlik TM, Wolfgang $\mathrm{CL}$, et al. Alternative lengthening of telomeres predicts site of origin in neuroendocrine tumor liver metastases. J Am Coll Surg. (2014) 218:62835. doi: 10.1016/j.jamcollsurg.2014.01.001

121. Roldo C, Missiaglia E, Hagan JP, Falconi M, Capelli P, Bersani S, et al. MicroRNA expression abnormalities in pancreatic endocrine and acinar tumors are associated with distinctive pathologic features and clinical behavior. J Clin Oncol. (2006) 24:4677-84. doi: 10.1200/JCO.2005.05.5194

122. Kentwell J, Gundara JS, Sidhu SB. Noncoding rNAs in endocrine malignancy. Oncologist. (2014) 19:483-91. doi: 10.1634/theoncologist.2013-0458

123. Young K, Starling N, Sadanandam A. The molecular biology of pancreatic neuroendocrine neoplasms: challenges and translational opportunities. Semin Cancer Biol. (2020) 61:132-8. doi: 10.1016/j.semcancer.2019.09.024

124. Mafficini A, Scarpa A. Genomic landscape of pancreatic neuroendocrine tumours: the international cancer genome consortium. J Endocrinol. (2018) 236:R161-R7. doi: 10.1530/JOE-17-0560

125. Mafficini A, Scarpa A. Genetics and epigenetics of gastroenteropancreatic neuroendocrine neoplasms. Endocr Rev. (2019) 40:50636. doi: 10.1210/er.2018-00160

126. Pea A, Yu J, Marchionni L, Noe M, Luchini C, Pulvirenti A, et al. Genetic analysis of small well-differentiated pancreatic neuroendocrine tumors identifies subgroups with differing risks of liver metastases. Ann Surg. (2020) 271:566-73. doi: 10.1097/SLA.0000000000003022

127. Scarpa A. The landscape of molecular alterations in pancreatic and small intestinal neuroendocrine tumours. Ann Endocrinol (Paris). (2019) 80:1538. doi: 10.1016/j.ando.2019.04.010

128. Pipinikas CP, Berner AM, Sposito T, Thirlwell C. The evolving (epi)genetic landscape of pancreatic neuroendocrine tumours. Endocr Relat Cancer. (2019) 26:R519-R44. doi: 10.1530/ERC-19-0175

129. Boons G, Vandamme T, Peeters M, Van Camp G, Op de Beeck K. Clinical applications of (epi)genetics in gastroenteropancreatic neuroendocrine neoplasms: moving towards liquid biopsies. Rev Endocr Metab Disord. (2019) 20:333-51. doi: 10.1007/s11154-019-09508-w

130. Jones S, Zhang X, Parsons DW, Lin JC-H, Leary RJ, Angenendt P, et al. Core signaling pathways in human pancreatic cancers revealed by global genomic analyses. Science. (2008) 321:1801-6. doi: 10.1126/science.1164368

131. Coriat R, Walter T, Terris B, Couvelard A, Ruszniewski P. Gastroenteropancreatic well-Differentiated grade 3 neuroendocrine tumors: review and position statement. Oncologist. (2016) 21:1191-9. doi: 10.1634/theoncologist.2015-0476

132. Fazio N, Milione M. Gastroenteropancreatic neuroendocrine carcinomas: the nET g3 subcategory is a reality. Oncologist. (2017) 22:359. doi: 10.1634/theoncologist.2016-0359 
133. Rindi G, Klöppel G, Alhman H, Caplin M, Couvelard A, De Herder WW, et al. TNM staging of foregut (neuro)endocrine tumors: a consensus proposal including a grading system. 395-401. doi: 10.1007/s00428-006-0250-1

134. Yachida S, Vakiani E, White CM, Zhong Y, Saunders T, Morgan R, et al. Small cell and large cell neuroendocrine carcinomas of the pancreas are genetically similar and distinct from well-differentiated pancreatic neuroendocrine tumors. Am J Surg Pathol. (2012) 36:173184. doi: 10.1097/PAS.0b013e3182417d36

135. La Rosa S, Sessa F. Pancreatic Neuroendocrine Neoplasms. Berlin: Springer. (2015).

136. Scarpa A, Mantovani W, Capelli P, Beghelli S, Boninsegna L, Bettini R, et al. Pancreatic endocrine tumors: improved tNM staging and histopathological grading permit a clinically efficient prognostic stratification of patients. Mod Pathol. (2010) 23:824-33. doi: 10.1038/modpathol.2010.58

137. Scardoni M, Vittoria E, Volante M, Rusev B, Bersani S, Mafficini A, et al. Mixed adenoneuroendocrine carcinomas of the gastrointestinal tract: targeted next-generation sequencing suggests a monoclonal origin of the two components. Neuroendocrinology. (2014) 100:310-6. doi: 10.1159/000369071

138. Ikeda M, Okuyama H, Takahashi H, Ohno I, Shimizu S, Mitsunaga S, et al. Chemotherapy for advanced poorly differentiated pancreatic neuroendocrine carcinoma. J Hepatobiliary Pancreat Sci. (2015) 22:6237. doi: $10.1002 / \mathrm{jhbp} .228$

139. Pizzi S, Azzoni C, Bassi D, Bottarelli L, Milione M, Bordi C. Genetic alterations in poorly differentiated endocrine carcinomas of the gastrointestinal tract. Cancer. (2003) 98:1273-82. doi: 10.1002/cncr.11621

140. Nassar H, Albores-Saavedra J, Klimstra DS. High-grade neuroendocrine carcinoma of the ampulla of vater: a clinicopathologic and immunohistochemical analysis of 14 cases. Am J Surg Pathol. (2005) 29:588-94. doi: 10.1097/01.pas.0000157974.05397.4f

141. Zhang H-Y, Rumilla KM, Jin L, Nakamura N, Stilling GA, Ruebel KH, et al. Association of dNA methylation and epigenetic inactivation of rASSF1A and beta-catenin with metastasis in small bowel carcinoid tumors. Endocrine. (2006) 30:299-306. doi: 10.1007/s12020-006-0008-1

142. Takizawa N, Ohishi Y, Hirahashi M, Takahashi S, Nakamura K, Tanaka $\mathrm{M}$, et al. Molecular characteristics of colorectal neuroendocrine carcinoma; similarities with adenocarcinoma rather than neuroendocrine tumor. Hum Pathol. (2015) 46:1890-900. doi: 10.1016/j.humpath.2015.08.006

143. Shivakumar L, Minna J, Sakamaki T, Pestell R, White MA. The rASSF1A tumor suppressor blocks cell cycle progression and inhibits cyclin d1 accumulation. Mol Cell Biol. (2002) 22:4309-18. doi: 10.1128/mcb.22.12.4309-4318.2002

144. Pizzi S, Azzoni C, Bottarelli L, Campanini N, D’Adda T, Pasquali C, et al. RASSF1A promoter methylation and $3 \mathrm{p} 21.3$ loss of heterozygosity are features of foregut, but not midgut and hindgut, malignant endocrine tumours. J Pathol. (2005) 206:409-16. doi: 10.1002/path.1784

145. La Rosa S, Marando A, Furlan D, Sahnane N, Capella C. Colorectal poorly differentiated neuroendocrine carcinomas and mixed adenoneuroendocrine carcinomas: insights into the diagnostic immunophenotype, assessment of methylation profile, and search for prognostic markers. Am J Surg Pathol. (2012) 36:601-11. doi: 10.1097/PAS.0b013e318242e21c

146. Furlan D, Sahnane N, Mazzoni M, Pastorino R, Carnevali I, Stefanoli $\mathrm{M}$, et al. Diagnostic utility of mS-MLPA in dNA methylation profiling of adenocarcinomas and neuroendocrine carcinomas of the colon-rectum. Virchows Arch. (2013) 462:47-56. doi: 10.1007/s00428-012-1348-2

147. Makuuchi R, Terashima M, Kusuhara M, Nakajima T, Serizawa M, Hatakeyama $\mathrm{K}$, et al. Comprehensive analysis of gene mutation and expression profiles in neuroendocrine carcinomas of the stomach. Biomed Res. (2017) 38:19-27. doi: 10.2220/biomedres.38.19

148. Nishikura K, Watanabe H, Iwafuchi M, Fujiwara T, Kojima K, Ajioka Y. Carcinogenesis of gastric endocrine cell carcinoma: analysis of histopathology and p53 gene alteration. Gastric Cancer. (2003) 6:2039. doi: 10.1007/s10120-003-0249-0

149. Vijayvergia N, Boland PM, Handorf E, Gustafson KS, Gong Y, Cooper HS, et al. Molecular profiling of neuroendocrine malignancies to identify prognostic and therapeutic markers: a fox chase cancer center pilot study. Br J Cancer. (2016) 115:564-70. doi: 10.1038/bjc.20 16.229
150. Bergsland EK, Roy R, Stephens P, Ross JS, Bailey M, Olshen A. Genomic profiling to distinguish poorly differentiated neuroendocrine carcinomas arising in different sites. J Clin Oncol. (2016) 34:40204020. doi: 10.1200/JCO.2016.34.15_suppl.4020

151. Tang LH, Basturk O, Sue JJ, Klimstra DS. A practical approach to the classification of who grade 3 (G3) well-differentiated neuroendocrine tumor (WD-NET) and poorly differentiated neuroendocrine carcinoma (PD-NEC) of the pancreas. Am J Surg Pathol. (2016) 40:1192-202. doi: 10.1097/PAS.0000000000000662

152. Sposito T, Tu M-SN, Rutter GA, Novelli M, Thirlwell C, Salomoni P. Abstract 5294: the panNET-related histone h3.3 chaperone daxx regulates lineage specification and tissue homeostasis in the pancreas. Cancer Res. (2019) 79:5294. doi: 10.1158/1538-7445.AM2019-5294

153. de Wilde RF, Heaphy CM, Maitra A, Meeker AK, Edil BH, Wolfgang CL, et al. Loss of aTRX or dAXX expression and concomitant acquisition of the alternative lengthening of telomeres phenotype are late events in a small subset of mEN-1 syndrome pancreatic neuroendocrine tumors. Mod Pathol. (2012) 25:1033-9. doi: 10.1038/modpathol.2012.53

154. Modlin IM, Kidd M, Malczewska A, Drozdov I, Bodei L, Matar S, et al. The nETest: the clinical utility of multigene blood analysis in the diagnosis and management of neuroendocrine tumors. Endocrinol Metab Clin North Am. (2018) 47:485-504. doi: 10.1016/j.ecl.2018.05.002

155. Zikusoka MN, Kidd M, Eick G, Latich I, Modlin IM. The molecular genetics of gastroenteropancreatic neuroendocrine tumors. Cancer. (2005) 104:2292309. doi: $10.1002 / \mathrm{cncr} .21451$

156. Scarpa A, Chang DK, Nones K, Corbo V, Patch A-M, Bailey P, et al. Wholegenome landscape of pancreatic neuroendocrine tumours. Nature. (2017) 543:65-71. doi: 10.1038/nature21063

157. Ohmoto A, Rokutan H, Yachida S. Pancreatic neuroendocrine neoplasms: basic biology, current treatment strategies and prospects for the future. IJMS. (2017) 18:143. doi: 10.3390/ijms18010143

158. Crippa S, Partelli S, Belfiori G, Palucci M, Muffatti F, Adamenko O, et al. Management of neuroendocrine carcinomas of the pancreas (WHO g3): a tailored approach between proliferation and morphology. WJG. (2016) 22:9944-53. doi: 10.3748/wjg.v22.i45.9944

159. Walls GV. Multiple endocrine neoplasia (MEN) syndromes. Semin Pediatr Surg. (2014) 23:96-101. doi: 10.1053/j.sempedsurg.2014.03.008

160. van Slegtenhorst M, de Hoogt R, Hermans C, Nellist M, Janssen B, Verhoef $\mathrm{S}$, et al. Identification of the tuberous sclerosis gene $\mathrm{tSC} 1$ on chromosome 9q34. Science. (1997) 277:805-8. doi: 10.1126/science.277.5327.805

161. Napolioni V, Curatolo P. Genetics and molecular biology of tuberous sclerosis complex. Curr Genomics. (2008) 9:47587. doi: $10.2174 / 138920208786241243$

162. Wallace MR, Marchuk DA, Andersen LB, Letcher R, Odeh HM, Saulino $\mathrm{AM}$, et al. Type 1 neurofibromatosis gene: identification of a large transcript disrupted in three nF1 patients. Science. (1990) 249:1816. doi: 10.1126/science. 2134734

163. Mukhopadhyay B, Sahdev A, Monson JP, Besser GM, Reznek RH, Chew SL. Pancreatic lesions in von hippel-Lindau disease. Clin Endocrinol (Oxf). (2002) 57:603-8. doi: 10.1046/j.1365-2265.2002.01637.x

164. Maher ER, Iselius L, Yates JR, Littler M, Benjamin C, Harris R, et al. Von hippel-Lindau disease: a genetic study. J Med Genet. (1991) 28:4437. doi: $10.1136 / \mathrm{jmg} \cdot 28.7 .443$

165. Thakker RV. Multiple endocrine neoplasia type 1 (MEN1). Best Pract Res Clin Endocrinol Metab. (2010) 24:355-70. doi: 10.1016/j.beem.2010.07.003

166. Lemmens I, Van de Ven WJ, Kas K, Zhang CX, Giraud S, Wautot V, et al. Identification of the multiple endocrine neoplasia type 1 (MEN1) gene. The European Consortium on MEN1. Hum Mol Genet. (1997) 6:117783. doi: $10.1093 / \mathrm{hmg} / 6.7 .1177$

167. Lemos MC, Thakker RV. Multiple endocrine neoplasia type 1 (MEN1): analysis of 1336 mutations reported in the first decade following identification of the gene. Hum Mutat. (2008) 29:22-32. doi: 10.1002/humu.20605

168. Perren A, Anlauf M, Henopp T, Rudolph T, Schmitt A, Raffel A, et al. Multiple endocrine neoplasia type 1 (MEN1): loss of one mEN1 allele in tumors and monohormonal endocrine cell clusters but not in islet hyperplasia of the pancreas. J Clin Endocrinol Metab. (2007) 92:111828. doi: 10.1210/jc.2006-1944 
169. Crona J, Skogseid B. GEP- nETS uPDATE: genetics of neuroendocrine tumors. Eur J Endocrinol. (2016) 174:R275-90. doi: 10.1530/EJE-15-0972

170. Kreutzfeldt S, Apostolidis L, Oles M, Horak P, Heilig CE, Heining C, et al. Abstract 919: clinical relevance of comprehensive genomic analysis in patients with advanced-stage neuroendocrine neoplasms: results from the mASTER trial of the german cancer consortium. Cancer Res. (2019) 79:9191. doi: 10.1158/1538-7445.AM2019-919

171. Corbo V, Dalai I, Scardoni M, Barbi S, Beghelli S, Bersani S, et al. MEN1 in pancreatic endocrine tumors: analysis of gene and protein status in 169 sporadic neoplasms reveals alterations in the vast majority of cases. Endocr Relat Cancer. (2010) 17:771-83. doi: 10.1677/ERC-10-0028

172. Swarts DRA, Scarpa A, Corbo V, Van Criekinge W, van Engeland M, Gatti G, et al. MEN1 gene mutation and reduced expression are associated with poor prognosis in pulmonary carcinoids. J Clin Endocrinol Metab. (2014) 99:E374-8. doi: 10.1210/jc.2013-2782

173. Hessman O, Lindberg D, Einarsson A, Lillhager P, Carling T, Grimelius L, et al. Genetic alterations on 3p, 11q13, and 18q in nonfamilial and mEN 1-associated pancreatic endocrine tumors. Genes Chromosomes Cancer. (1999) 26:258-64.

174. Milne TA, Hughes CM, Lloyd R, Yang Z, Rozenblatt-Rosen O, Dou $\mathrm{Y}$, et al. Menin and mLL cooperatively regulate expression of cyclindependent kinase inhibitors. Proc Natl Acad Sci USA. (2005) 102:74954. doi: $10.1073 /$ pnas. 0408836102

175. Wang Y, Ozawa A, Zaman S, Prasad NB, Chandrasekharappa SC, Agarwal SK, et al. The tumor suppressor protein menin inhibits aKT activation by regulating its cellular localization. Cancer Res. (2011) 71:37182. doi: 10.1158/0008-5472.CAN-10-3221

176. Fang M, Xia F, Mahalingam M, Virbasius C-M, Wajapeyee N, Green MR. MEN1 is a melanoma tumor suppressor that preserves genomic integrity by stimulating transcription of genes that promote homologous recombination-directed dNA repair. Mol Cell Biol. (2013) 33:263547. doi: 10.1128/MCB.00167-13

177. Francis J, Lin W, Rozenblatt-Rosen O, Meyerson M. The menin tumor suppressor protein is phosphorylated in response to dNA damage. PLoS ONE. (2011) 6:e16119. doi: 10.1371/journal.pone.0016119

178. Borsari S, Pardi E, Pellegata NS, Lee M, Saponaro F, Torregrossa $\mathrm{L}$, et al. Loss of p27 expression is associated with mEN1 gene mutations in sporadic parathyroid adenomas. Endocrine. (2017) 55:38697. doi: 10.1007/s12020-016-0941-6

179. Sorbye H, Baudin E, Borbath I, Caplin M, Chen J, Cwikla JB, et al. Unmet needs in high-Grade gastroenteropancreatic neuroendocrine neoplasms (WHO g3). Neuroendocrinology. (2019) 108:54-62. doi: 10.1159/000493318

180. Schmitt AM, Schmid S, Rudolph T, Anlauf M, Prinz C, Klöppel G, et al. VHL inactivation is an important pathway for the development of malignant sporadic pancreatic endocrine tumors. Endocr Relat Cancer. (2009) 16:121927. doi: 10.1677/ERC-08-0297

181. Johannessen CM, Reczek EE, James MF, Brems H, Legius E, Cichowski K. The $\mathrm{nF} 1$ tumor suppressor critically regulates $\mathrm{tSC} 2$ and mTOR. Proc Natl Acad Sci USA. (2005) 102:8573-8. doi: 10.1073/pnas.0503224102

182. Missiaglia E, Dalai I, Barbi S, Beghelli S, Falconi M, Peruta della $M$, et al. Pancreatic endocrine tumors: expression profiling evidences a role for aKT-mTOR pathway. J Clin Oncol. (2010) 28:245-55. doi: 10.1200/JCO.2008.21.5988

183. Starker LF, Carling T. Molecular genetics of gastroenteropancreatic neuroendocrine tumors. Curr Opin Oncol. (2009) 21:2933. doi: 10.1097/CCO.0b013e328319ea7b

184. Nagano Y, Kim DH, Zhang L, White JA, Yao JC, Hamilton SR, et al. Allelic alterations in pancreatic endocrine tumors identified by genomewide single nucleotide polymorphism analysis. Endocr Relat Cancer. (2007) 14:483-92. doi: 10.1677/ERC-06-0090

185. Capurso G, Festa S, Valente R, Piciucchi M, Panzuto F, Jensen RT, et al. Molecular pathology and genetics of pancreatic endocrine tumours. J Mol Endocrinol. (2012) 49:R37-50. doi: 10.1530/JME-12-0069

186. Esposito I, Segler A, Steiger K, Klöppel G. Pathology, genetics and precursors of human and experimental pancreatic neoplasms: an update. Pancreatology. (2015) 15:598-610. doi: 10.1016/j.pan.2015.08.007

187. Kim DH, Nagano Y, Choi I-S, White JA, Yao JC, Rashid A. Allelic alterations in well-differentiated neuroendocrine tumors (carcinoid tumors) identified by genome-wide single nucleotide polymorphism analysis and comparison with pancreatic endocrine tumors. Genes Chromosomes Cancer. (2008) 47:84-92. doi: $10.1002 / \mathrm{gcc} .20510$

188. Sadanandam A, Wullschleger S, Lyssiotis CA, Grötzinger C, Barbi S, Bersani S, et al. A cross-Species analysis in pancreatic neuroendocrine tumors reveals molecular subtypes with distinctive clinical, metastatic, developmental, and metabolic characteristics. Cancer Discov. (2015) 5:1296313. doi: 10.1158/2159-8290.CD-15-0068

189. Malpeli G, Amato E, Dandrea M, Fumagalli C, Debattisti V, Boninsegna $\mathrm{L}$, et al. Methylation-associated down-regulation of rASSF1A and upregulation of rASSF1C in pancreatic endocrine tumors. BMC Cancer. (2011) 11:351. doi: 10.1186/1471-2407-11-351

190. Stefanoli M, La Rosa S, Sahnane N, Romualdi C, Pastorino R, Marando A, et al. Prognostic relevance of aberrant dNA methylation in g1 and g2 pancreatic neuroendocrine tumors. Neuroendocrinology. (2014) 100:264. doi: $10.1159 / 000365449$

191. House MG, Herman JG, Guo MZ, Hooker CM, Schulick RD, Lillemoe KD, et al. Aberrant hypermethylation of tumor suppressor genes in pancreatic endocrine neoplasms. Ann Surg. (2003) 238:423-31- discussion 4312. doi: 10.1097/01.sla.0000086659.49569.9e

192. Marinoni I, Wiederkeher A, Wiedmer T, Pantasis S, Di Domenico A, Frank $\mathrm{R}$, et al. Hypo-methylation mediates chromosomal instability in pancreatic nET. Endocr Relat Cancer. (2017) 24:137-46. doi: 10.1530/ERC-16-0554

193. Di Domenico A, Wiedmer T, Marinoni I, Perren A. Genetic and epigenetic drivers of neuroendocrine tumours (NET). Endocr Relat Cancer. (2017) 24:R315-R34. doi: 10.1530/ERC-17-0012

194. Öberg K, Califano A, Strosberg JR, Ma S, Pape U, Bodei L, et al. A meta-analysis of the accuracy of a neuroendocrine tumor mRNA genomic biomarker (NETest) in blood. Ann Oncol. (2020) 31:20212. doi: 10.1016/j.annonc.2019.11.003

195. Brabander T, van der Zwan WA, Teunissen JJM, Kam BLR, de Herder WW, Feelders RA, et al. Pitfalls in the response evaluation after peptide receptor radionuclide therapy with [177Lu-DOTA0,Tyr3] octreotate. Endocr Relat Cancer. (2017) 24:243-51. doi: 10.1530/ERC-16-0524

196. Capdevila J, Casanovas O, Salazar R, Castellano D, Segura A, Fuster P, et al. Translational research in neuroendocrine tumors: pitfalls and opportunities. Oncogene. (2017) 36:1899-907. doi: 10.1038/onc.2016.316

197. Toumpanakis C, Kim MK, Rinke A, Bergestuen DS, Thirlwell C, Khan MS, et al. Combination of cross-sectional and molecular imaging studies in the localization of gastroenteropancreatic neuroendocrine tumors. Neuroendocrinology. (2014) 99:63-74. doi: 10.1159/000358727

198. Bodei L, Sundin A, Kidd M, Prasad V, Modlin IM. The status of neuroendocrine tumor imaging: from darkness to light? Neuroendocrinology. (2015) 101:1-7. doi: 10.1159/000367850

199. de Mestier L, Dromain C, d'Assignies G, Scoazec J-Y, Lassau N, Lebtahi $\mathrm{R}$, et al. Evaluating digestive neuroendocrine tumor progression and therapeutic responses in the era of targeted therapies: state of the art. Endocr Relat Cancer. (2014) 21:R105-20. doi: 10.1530/ERC-13-0365

200. Yang Z, Tang LH, Klimstra DS. Effect of tumor heterogeneity on the assessment of ki67 labeling index in well-differentiated neuroendocrine tumors metastatic to the liver: implications for prognostic stratification. Am J Surg Pathol. (2011) 35:853-60. doi: 10.1097/PAS.0b013e31821 a0696

201. Frank R, Hargreaves R. Clinical biomarkers in drug discovery and development. Nat Rev Drug Discov. (2003) 2:566-80. doi: 10.1038/nrd1130

202. Zatelli MC, Grossrubatscher EM, Guadagno E, Sciammarella C, Faggiano A, Colao A. Circulating tumor cells and miRNAs as prognostic markers in neuroendocrine neoplasms. Endocr Relat Cancer. (2017) 24:R223R37. doi: 10.1530/ERC-17-0091

203. Cwikła JB, Bodei L, Kolasinska-Cwikła A, Sankowski A, Modlin IM, Kidd M. Circulating transcript analysis (NETest) in gEP-NETs treated with somatostatin analogs defines therapy. J Clin Endocrinol Metab. (2015) 100:E1437-45. doi: 10.1210/jc.2015-2792

204. Rizzo FM, Meyer T. Liquid biopsies for neuroendocrine tumors: circulating tumor cells, dNA, and microRNAs. Endocrinol Metab Clin North Am. (2018) 47:471-83. doi: 10.1016/j.ecl.2018.04.002

205. Rizzo FM, Vesely C, Childs A, Marafioti T, Khan MS, Mandair D, et al. Circulating tumour cells and their association with bone metastases in 
patients with neuroendocrine tumours. Br J Cancer. (2019) 120:294300. doi: 10.1038/s41416-018-0367-4

206. Li S-C, Essaghir A, Martijn C, Lloyd RV, Demoulin J-B, Öberg K, Giandomenico V. Global microRNA profiling of well-differentiated small intestinal neuroendocrine tumors. Mod Pathol. (2013) 26:68596. doi: 10.1038/modpathol.2012.216

207. Thorns C, Schurmann C, Gebauer N, Wallaschofski H, Kümpers C, Bernard $\mathrm{V}$, et al. Global microRNA profiling of pancreatic neuroendocrine neoplasias. Anticancer Res. (2014) 34:2249-54.

208. Lee YS, Kim H, Kim HW, Lee J-C, Paik K-H, Kang J, et al. High expression of microRNA-196a indicates poor prognosis in resected pancreatic neuroendocrine tumor. Medicine (Baltimore). (2015) 94:e2224. doi: 10.1097/MD.0000000000002224

209. He C, Dong X, Zhai B, Jiang X, Dong D, Li B, et al. MiR-21 mediates sorafenib resistance of hepatocellular carcinoma cells by inhibiting autophagy via the pTEN/Akt pathway. Oncotarget. (2015) 6:2886781. doi: $10.18632 /$ oncotarget.4814

210. Brunner AL, Beck AH, Edris B, Sweeney RT, Zhu SX, Li R, et al. Transcriptional profiling of long non-coding rNAs and novel transcribed regions across a diverse panel of archived human cancers. Genome Biol. (2012) 13:R75. doi: 10.1186/gb-2012-13-8-r75

211. Gutschner T, Diederichs $S$. The hallmarks of cancer: a long non-coding rNA point of view. RNA Biol. (2012) 9:703-19. doi: 10.4161/rna.20481

212. Raveh E, Matouk IJ, Gilon M, Hochberg A. The h19 long non-coding rNA in cancer initiation, progression and metastasis - a proposed unifying theory. Mol Cancer. (2015) 14:184. doi: 10.1186/s12943-015-0458-2

213. Matouk I, Raveh E, Ohana P, Lail RA, Gershtain E, Gilon M, et al. The increasing complexity of the oncofetal h19 gene locus: functional dissection and therapeutic intervention. IJMS. (2013) 14:4298316. doi: $10.3390 /$ ijms 14024298

214. Ji M, Tang L, Ding R, Shi L, Liu A, Chen D, et al. Long noncoding rNA-mRNA expression profiles and validation in pancreatic neuroendocrine neoplasms. Clin Endocrinol (Oxf). (2020) 92:312-22. doi: 10.1111/cen.14156

215. Kidd M, Drozdov I, Modlin I. Blood and tissue neuroendocrine tumor gene cluster analysis correlate, define hallmarks and predict disease status. Endocr Relat Cancer. (2015) 22:561-75. doi: 10.1530/ERC-15-0092

216. Modlin IM, Aslanian H, Bodei L, Drozdov I, Kidd M. A pCR blood test outperforms chromogranin a in carcinoid detection and is unaffected by proton pump inhibitors. Endocr Connect. (2014) 3:21523. doi: 10.1530/EC-14-0100

217. Genzen JR, Mohlman JS, Lynch JL, Squires MW, Weiss RL. LaboratoryDeveloped tests: a Legislative and regulatory review. Clin Chem. (2017) 63:1575-84. doi: 10.1373/clinchem.2017.275164

218. Modlin IM, Drozdov I, Kidd M. The identification of gut neuroendocrine tumor disease by multiple synchronous transcript analysis in blood. PLoS ONE. (2013) 8:e63364. doi: 10.1371/journal.pone.0063364

219. Pavel M, Jann H, Prasad V, Drozdov I, Modlin IM, Kidd M. NET blood transcript analysis defines the crossing of the clinical rubicon: when stable disease becomes progressive. Neuroendocrinology. (2017) 104:170182. doi: $10.1159 / 000446025$

220. Kidd M, Modlin IM, Drozdov I, Aslanian H, Bodei L, Matar S, et al. A liquid biopsy for bronchopulmonary/lung carcinoid diagnosis. Oncotarget. (2018) 9:7182-96. doi: 10.18632/oncotarget.23820

221. Filosso PL, Kidd M, Roffinella M, Lewczuk A, Chung K-M, KolasinskaCwikla A, et al. The utility of blood neuroendocrine gene transcript measurement in the diagnosis of bronchopulmonary neuroendocrine tumours and as a tool to evaluate surgical resection and disease progression. Eur J Cardiothorac Surg. (2018) 53:631-9. doi: 10.1093/ejcts/ezx386

222. van Treijen MJC, Korse CM, van Leeuwaarde RS, Saveur LJ, Vriens MR, Verbeek WHM, et al. Blood transcript profiling for the detection of neuroendocrine tumors: results of a large independent validation study. Front Endocrinol (Lausanne). (2018) 9:740. doi: 10.3389/fendo.2018.00740

223. Al-Toubah TE, Cives M, Valone T, Blue K, Strosberg JR. Sensitivity and specificity of the nETest: a validation study. J Clin Oncol. (2019) 37:222. doi: 10.1200/JCO.2019.37.4_suppl.222

224. Malczewska A, Öberg K, Bodei L, Aslanian H, Lewczuk A, Filosso PL, et al. NETest liquid biopsy is diagnostic of lung neuroendocrine tumors and identifies progressive disease. Neuroendocrinology. (2019) 108:21931. doi: $10.1159 / 000497037$

225. Malczewska A, Witkowska M, Makulik K, Bocian A, Walter A, PilchKowalczyk J, et al. NETest liquid biopsy is diagnostic of small intestine and pancreatic neuroendocrine tumors and correlates with imaging. Endocr Connect. (2019) 8:442-53. doi: 10.1530/EC-19-0030

226. Liu E, Paulson S, Gulati A, Freudman J, Grosh W, Kafer S, et al. Assessment of nETest clinical utility in a US. Registry-based study. Oncologist. (2019) 24:783-90. doi: 10.1634/theoncologist.2017-0623

227. Bodei L, Kidd MS, Singh A, van der Zwan WA, Severi S, Drozdov IA, et al. PRRT neuroendocrine tumor response monitored using circulating transcript analysis: the nETest. Eur J Nucl Med. (2020) 47:895906. doi: 10.1007/s00259-019-04601-3

228. Bodei L, Kidd M, Modlin IM, Severi S, Drozdov I, Nicolini S, et al. Measurement of circulating transcripts and gene cluster analysis predicts and defines therapeutic efficacy of peptide receptor radionuclide therapy (PRRT) in neuroendocrine tumors. Eur J Nucl Med. (2016) 43:83951. doi: $10.1007 / \mathrm{s} 00259-015-3250-\mathrm{z}$

229. Bodei L, Kidd MS, Singh A, van der Zwan WA, Severi S, Drozdov I, et al. Peptide receptor radionuclide therapy (PRRT) transcriptomic signature in blood for prediction of 177lu-octreotate efficacy. J Clin Oncol. (2018) 36:4101. doi: 10.1200/JCO.2018.36.15_suppl.4101

230. Bodei L, Kidd MS, Singh A, van der Zwan WA, Severi S, Drozdov IA, et al. PRRT genomic signature in blood for prediction of $177 \mathrm{Lu}$-octreotate efficacy. Eur J Nucl Med. (2018) 45:1155-69. doi: 10.1007/s00259-018-3967-6

231. Kidd M, Modlin IM. Therapy: the role of liquid biopsies to manage and predict pRRT for nETs. Nat Rev Gastroenterol Hepatol. (2017) 14:3312. doi: $10.1038 /$ nrgastro.2017.26

232. Genç CG, Jilesen APJ, Nieveen van Dijkum EJM, Klümpen H-J, van Eijck $\mathrm{CHJ}$, Drozdov I, et al. Measurement of circulating transcript levels (NETest) to detect disease recurrence and improve follow-up after curative surgical resection of well-differentiated pancreatic neuroendocrine tumors. J Surg Oncol. (2018) 118:37-48. doi: 10.1002/jso.25129

233. Malczewska A, Witkowska M, Wójcik-Giertuga M, Kuśnierz K, Bocian A, Walter A, et al. Prospective evaluation of the nETest as a liquid biopsy for gastroenteropancreatic and bronchopulmonary neuroendocrine tumours: an eNETS centre of excellence experience. Neuroendocrinology. (2020). doi: $10.1159 / 000508106$

234. Partelli S, Andreasi V, Muffatti F, Schiavo Lena M, Falconi M. Circulating neuroendocrine gene transcripts (NETest): a Postoperative strategy for early identification of the efficacy of radical surgery for pancreatic neuroendocrine tumors. Ann Surg Oncol. (2020) 108:219-31. doi: 10.1245/s10434-020-08425-6

235. Xiong M, Wang F, Zhau HE, Huang X, Chung L, Zhang J, et al. Abstract 3295: gPRASP1:A novel potential biomarker for neuroendocrine carcinoma. Cancer Res. (2019) 79:3295. doi: 10.1158/1538-7445.AM2019-3295

236. Owonikoko T, Smit M, Borghaei H, Salgia R, Boyer M, Rasmussen E, et al. OA13.02 two novel immunotherapy agents targeting dLL3 in sCLC: trials in progress of aMG 757 and aMG 119. J Thor Oncol. (2018) 13:S351. doi: 10.1016/j.jtho.2018.08.307

237. Rudin CM, Pietanza MC, Bauer TM, Ready N, Morgensztern D, Glisson BS, et al. Rovalpituzumab tesirine, a dLL3-targeted antibodydrug conjugate, in recurrent small-cell lung cancer: a first-in-human, first-in-class, open-label, phase 1 study. Lancet Oncol. (2017) 18:4251. doi: 10.1016/S1470-2045(16)30565-4

Conflict of Interest: The authors declare that the research was conducted in the absence of any commercial or financial relationships that could be construed as a potential conflict of interest.

Copyright $\odot 2020$ Bocchini, Nicolini, Severi, Bongiovanni, Ibrahim, Simonetti, Grassi and Mazza. This is an open-access article distributed under the terms of the Creative Commons Attribution License (CC BY). The use, distribution or reproduction in other forums is permitted, provided the original author(s) and the copyright owner(s) are credited and that the original publication in this journal is cited, in accordance with accepted academic practice. No use, distribution or reproduction is permitted which does not comply with these terms. 